\title{
THE ORIGIN AND DEVELOPMENT OF THE EAST EUROPEAN TAIGA IN LATE CENOZOIC
}

\section{N. Kalyakin}

Zoological Museum of Moscow State University, 6 Nikitskaya street, Moscow, 125009, Russia

E-mail:kalyakiny1939@mail.ru

\section{S. A. Turubanova}

University of Maryland, College Park, Le Frak Hall, 20742, MD, USA

E-mail:paleobase@gmail.com

\section{O. V. Smirnova}

Center for ecological and forest productivity problems, 84/32 Profsoyuznaya street, Moscow, 117810, Russia

E-mail: ovsinfo@gmail.com

\section{ПРОИСХОЖАЕНИЕ И РАЗВИТИЕ ВОСТОЧНОЕВРОПЕЙСКОЙ ТАЙГИ В ПОЗАНЕМ КАЙНОЗОЕ}

\section{В. Н. Калякин}

Зоологический музей Московского государственного университета, 1250о9, Россия, г. Москва, ул. Большая Никитская, 6 E-mail:kalyakiny1939@mail.ru

\section{С. А. Турубанова}

Университет шата Мэриленд, США, Мэриленд, 20742 Ле Фрак Холл,Колледж Парк E-mail:paleobase@gmail.com

\section{О. В. Смирнова}

Центр по проблемам экологии и продуктивности лесов РАН, 117485, Россия, г. Москва, ул. Профсоюзная, 84/32 E-mail: ovsinfo@gmail.com

Abstract. The authors suggest a new aspect of origin and development of the East European boreal forest. Innovative ideas and new data allowed to analyze the genesis of the ecosystem cover by creating a series of model reconstructions of different historical periods with different intensity and forms of human activity. Paleobiological reconstruction of teriofauna and denroflora since the late Pliocene to the present allows assuming that the initial vegetation type for boreal forests was Pliocene coniferous-broad-leaved savanna-looking forests of Northern Eurasia, where large herbivores (giant species of the mammoth complex) affected biota the most. At the end of Pleistocene the loss of the key species' role of large and giant herbivores for grassland ecosystems was a crucial step in the irreversible transformation of the terrestrial ecosystem. During Holocene forest vegetation split into boreal (taiga), nemoral-boreal and nemoral zones as a result of human activities.

Key words: boreal forests, palynological and osteological database, keystone species, model reconstructions, ecosystems history, Pleistocene, Holocene.

For citation: Kalyakin V.N., Turubanova S.A., Smirnova O.V. The origin and development of the east European taiga in late Cenozoic. Russian Journal of Ecosystem Ecology. 2016;1(1). Available from: https://doi.org/10.21685/2500-0578-2016-1-2

Аннотация. В данной работе авторы поставили цель пересмотреть представления о современной европейской тайге как естественном типе растительности, сформировавшемся в результате исключительно природных процессов, и обосновать представлении о доминирующей роли антропогенной деятельности в формировании этого типа растительности. Инновационные идеи и новые данные позволили проанализировать различные исторические периоды, характеризующиеся различной интенсивностью и формами активности человека. Палеобиологическая реконструкция териофауны и дендрофлоры от позднего Плиоцена до наших дней позволяет сделать предположение, что первоначальным видом растительности бореальных лесов Плиоцена были хвойно-широколиственные саванные леса Северной Евразии, где крупные травоядные животные (гигантские виды мамонтового комплекса) больше всего оказывали влияние на флору и фауну данной территории. В конце Плейстоцена утрата роли ключевого вида крупными и гигантскими травоядными для травянистых экосистем стало критическим этапом в необратимой трансформации наземной экоси- 
стемы. В период Голоцена лесная растительность разделилась на бореальную (тайга), неморальнобореальную и неморальную зоны в результате деятельности человека.

Ключевые слова: бореальные леса, полинологические и остеологические базы данных, ключевые виды, модельная реконструкция, история экосистем, плейстоцен, голоцен.

\section{Introduction}

The origin and development of boreal forests of Northern Eurasia has been discussed for decades [1-10]. Another reference to this problem (based on the example from the Eastern European part of the boreal zone) is due to several reasons.

Firstly, the modern theories in synecology show that formation and development of forest ecosystems were affected by keystone species - not only plants, but also animals. These species play a critical role in maintaining the structure of an ecological community, affecting many other organisms in an ecosystem and helping to determine the types and numbers of other various species in the community [10]. In this regard the study of the genesis of boreal forests is possible only through analyzing changes in the composition of both flora and fauna, specifically the keystone species. Accumulated paleontological data is a necessary factual basis for reconstruction modelling of the ecosystem cover.

Secondly, the analysis of the terrestrial ecosystems history since the end of the Pliocene to the present has shown that humans acted as a powerful keystone species, determining composition and structure of actual vegetation even before the producing economy development [10-19].

Therefore, innovative ideas and new data allowed to analyze the genesis of the ecosystem cover by creating a series of model reconstructions of different historical periods with different intensity and forms of human activity. In this article we describe such experience for Eastern Europe.

Objectives: A. series of reconstruction models of formation and development of the taiga (boreal forest) in Eastern Europe since the end of the Pleistocene to nowadays based on comparison of extinct and existing key species of animals and plants expansion, as well as associated assemblies of subordinate(indicator) species;

B. revision of existing hypotheses of the origin of the Eurasian taiga based on the analysis of literature and the data on the key plant and animal species expansion dynamics.

\section{Methods and objects}

The basis of the methodology for reconstruction of the boreal zone of Eastern Europe is the idea of the transforming role of key plant and animal species and subordinate species $[8,10,18,19]$. Since population dynamics of key species creates the necessary conditions for sustainable habitats of subordinate species, paleontological data of key species presence allows an indirect suggestion about existence of the relevant ecosystems in general.

The mapping methods of former and actual area include as follows:

1. Selection of key and subordinate (indicator) species;

2. Creation of databases i. a palynological and an osteological databases, reported data on locations of the chosen species, herbarium data (the "Areal" database); ii. geobotanical field descriptions from refugia of the boreal forest - the "Forest vegetation of Northern Eurasia" database;

3. Creation of GIS-maps for different time periods from the end of the Pleistocene to nowadays. Table 1 shows synchronization of geochronological and archaeological scales from the end of the Pleistocene to the Holocene.

Key animal species:

A. extinct everywhere or only in Eurasia: giant deer (Megaloceros giganteus Blumenbach), prehistoric bison (Bison priscus Bojanus), musk ox (Ovibos moschatus Zimmermann), woolly rhinoceros (Coelodonta antiquitatis Blumenbach), Mammoth (Mammuthus primigenius Blumenbach), including species that became instinct during last centuries: wild horse (Equus Linnaeus (sp.)), auroch (Bos primigenius Bojanus), bison (Bison bonasus Linnaeus). Bison was close to extinction in the beginning of the 20 century, but thanks to special efforts its population was restored on limited areas.

B. survived and/or partially restoring its historic areas: European beaver (Castor fiber Linnaeus), wild boar (Sus scrofa Linnaeus), red deer (Cervus elaphus Linnaeus), roe deer (Capreolus capreolus Linnaeus), moose (Alces alces Linnaeus), reindeer (Rangifer tarandus Linnaeus), saiga (Saiga tatarica Linnaeus).

Key plant species survived to nowadays and/or partially restoring its historic areas: species of the genus oak (Quercus sp.), beech (Fagus sp.), ash (Fraxinus sp.), maple (Acer sp.), linden (Tilia sp.), elm (Ulmus sp.), hornbeam (Carpinus sp.), hazel (Corylus sp.), spruce (Picea sp.), fir (Abies sp.), cedar pine (Pinus sibirica). In the pollen spectra, plant macrofossils, data from historical sources and toponyms of trees are determined by genus. The herbarium materials and geobotanical data are listed by the species. 
Cross-discipline correlation of the Holocene

\begin{tabular}{|c|c|c|c|c|c|}
\hline \multicolumn{5}{|c|}{ Geochronological classification } & \multirow{3}{*}{$\begin{array}{l}\text { Archeological } \\
\text { classification } \\
\text { (Bader, 1974) }\end{array}$} \\
\hline \multicolumn{2}{|c|}{ The sequence (Neistadt, 1957) } & \multicolumn{3}{|c|}{$\begin{array}{c}\text { The sequence by Blytt-Sernander } \\
\text { (Khotinsky, 1982) }\end{array}$} & \\
\hline \multicolumn{2}{|c|}{ stage } & \multicolumn{2}{|c|}{ stage } & dating, BP & \\
\hline $\begin{array}{l}\text { Late Holocene } \\
\qquad(\mathrm{HL}-4)\end{array}$ & $0-2500$ & subatlantic & $\begin{array}{l}\text { SA-3 } \\
\text { SA-2 } \\
\text { SA-1 }\end{array}$ & $\begin{array}{c}800 \\
1800 \\
2500\end{array}$ & Iron age \\
\hline \multirow{2}{*}{$\begin{array}{l}\text { Middle Holocene } \\
\qquad \text { (HL-3) }\end{array}$} & \multirow{2}{*}{$2500-7700$} & subboreal & $\begin{array}{l}\text { SB-3 } \\
\text { SB-2 } \\
\text { SB-1 }\end{array}$ & $\begin{array}{l}3200 \\
4200 \\
4600\end{array}$ & Bronze age \\
\hline & & atlantic & $\begin{array}{l}\text { AT-3 } \\
\text { AT-2 } \\
\text { AT-1 }\end{array}$ & $\begin{array}{l}6000 \\
7000 \\
8000\end{array}$ & Neolith \\
\hline \multirow{2}{*}{$\begin{array}{l}\text { Early Holocene } \\
\text { (HL-2) }\end{array}$} & \multirow{2}{*}{$7700-9800$} & \multirow[b]{2}{*}{ preborcal } & $\begin{array}{l}\text { BO-3 } \\
\text { BO-2 } \\
\text { BO-1 }\end{array}$ & $\begin{array}{l}8300 \\
8900 \\
9300\end{array}$ & \multirow[t]{2}{*}{ Mesolith } \\
\hline & & & $\begin{array}{l}\text { PB-2 } \\
\text { PB-1 }\end{array}$ & $\begin{array}{l}10000 \\
10300\end{array}$ & \\
\hline $\begin{array}{l}\text { Older Holocene } \\
(\text { HL-1) }\end{array}$ & $9800-12000$ & $\begin{array}{c}\text { Dryas } \\
\text { Allerod } \\
\end{array}$ & $\begin{array}{l}\mathrm{Dr} \\
\Lambda \mathrm{l} \\
\end{array}$ & $\begin{array}{l}11000 \\
12000\end{array}$ & \multirow[t]{2}{*}{ Paleolith } \\
\hline \multicolumn{4}{|c|}{ Late Pleistocene } & $\begin{array}{l}13000 \\
40000\end{array}$ & \\
\hline
\end{tabular}

Maps were created not only for every chosen species but also for the following types: dark coniferous (spruce, fir, cedar pine) and broad-leaved (oak, beech, linden, maple, ash, elm, hornbeam and hazel). All locations of representatives of at least one tree genus from a certain type were considered for mapping a type area.

Indicator plant species were sorted by two complexes: "nemoral" - associated with formation of deciduous broad-leaved trees, and "boreal" - related to formation of dark coniferous (evergreen) trees.

The "nemoral" complex includes two groups differing by its phenology: 1 . spring ephemeroids: species of the following genera: Anemone, Corydalis, Dentaria, Gagea, and 2.tall herbs and grasses: Aegopodium podagraria L., Asarum europaeum L., Convallaria majalis L., Carexpilosa Scop., Galeobdolon luteum Huds., Lathyrus vernus (L.) Bernh., Melica nutans L., Mercurialis perennis L., Milium effusum L., Paris quadrifoila L., Polygonatum multiflorum (L.) All., Poa nemoralis L., Pulmonaria obscura Dumort., Ranunculus cassubicus L., Stellaria holostea L., Viola mirabilis L.

The "boreal" complex includes evergreen grass and shrubs: Circaea alpine L., Goodyera repens (L.) R. Br. in Aiton \& W.T. Aiton, Gymnocarpium dryopteris (L.) Newman, Linnaea borealis (L.) R. Br., Listera cordata (L.) R. Br., Luzula pilosa (L.) Willd., Maianthemum bifolium (L.) F.W. Schmidt, Moneses uniflora (L.) A. Gray, Oxalis acetosella L., Orthilia secunda (L.) House, Phegopteris con- nectilis (Michx.) Watt, Pyrola media Sw., P. minor L., P. rotundifolia L., Trientalis europaea L., Vaccinium myrtillus L., Viola selkirkii Pursh ex Goldie and others [20].

Simultaneous presence of the indicator species in the modern boreal forest we assumed as simultaneous presence of key species in the Past.

Indicator animal species are combined in two complexes, nemoral (deciduous) and forest in general:

Nemoral species are species whose habitats are now confined mainly to the area of present distribution of broad-leaved and coniferous-broadleaved forests. It is common hedgehog (Erinaceus europaeus Linnaeus), muskrat (Desmana moschata Linnaeus), ordinary mole (Talpa europaea Linnaeus), polecat (Mustela putorius Linnaeus), wild boar (Sus scrofa), red deer (Cervus elaphus), loir (Glis glis Linnaeus) and dormouse: forest dormouse (Dryomys nitedula Pallas), garden dormouse (Eliomys quercinus Linnaeus), hazel dormouse (Muscardinus avellanarius Linnaeus), field mouse (Apodemus agrarius Pallas), three species of forest mice (Sylvaemus Ognev), voles: common pine vole (Microtus subterraneus Selys-Longchamps) and bank vole (Clethrionomys glareolus Schreber).

Forest species in general are species whose habitats are now confined to the entire forest zone, some of them live in the forest tundra and/or the forest steppe: brown bear (Ursus arctos Linnaeus), pine marten (Martes martes Linnaeus), sable (Martes zibellina Linnaeus), European mink 
(Mustela lutreola Linnaeus), speakers (Mustela sibirica Pallas), wolverine (Gulo gulo Linnaeus), lynx (Lynx lynx Linnaeus), moose (Alces alces), red squirrel (Sciurus vulgaris Linnaeus), flying squirrel (Pteromys volans Linnaeus), chipmunk (Tamias sibiricus Laxmann), beaver (Castor fiber), three species of the genus of forest voles (Clethrionomys Tilesius): red-haired, red-gray (C. rufocanus Sundervall) and red vole (C. rutilus Pallas), dark vole (Microtus agrestis Linnaeus) and wood lemming (Myopus schisticolor Lilljeborg).

Species, that were earlier [21] considered boreal, have spread wider [22], therefore, they are included in the forest group. The presence of nemoral plant species and small vertebrates in modern boreal forests is considered as an evidence of former presence of broad-leaved trees [23]. The presence of the same boreal species of shrubs, grasses and small vertebrates from the tundra [24] through the steppes [25] is considered as an evidence of a wider spread of coniferous forests in Eastern Europe.

Research methods and detailed descriptions of the refugia of natural nemoral, hemiboreal and boreal forests were published in a series of articles and monographs $[8,9,10,16,24,26]$.

\section{Brief description of model reconstructions of ecosystems of the contemporary forests of Eastern Europe from the late Pleistocene to nowadays}

The wood-pasture landscape dominated on the territory of Northern Eurasia not only during the Late Cenozoic (Pliocene to Pleistocene and up to the present), but for some immeasurably longer time. Forest ecosystems were largely confined to the river valleys and slopes including mountain slopes. We agree with the views of A. Krishtofovich that "...different facts stand for the development of grassy plains... even later than the Eocene and probably since the Cretaceous period, the century of dinosaurs..." [27, p. 67]. The data analysis $[28,29]$ conducted by us [19] shows that in the Late Cretaceous (after appearance of angiosperms) the number of genera of dinosaurs herbivores and dinosaurs carnivores drastically (3-3.5 times) increased compared to the Early Cretaceous. At the same time diverse mammal fauna appeared after extinction of dinosaurs, pterosaurs, and several other groups of animals. Large mammals herbivores and large creodonta appeared already in the Palaeocene [28].

In general large herbivores are known even earlier, in the Paleozoic, since the Late Carboniferous -
Early Permian. Grassland pasture ecosystems were formed mainly by ferns before the development of angiosperms according to A. N. Krishtofovich [27].

Therefore, the analysis shows a long history of pastoral grassland ecosystems formed on the basis of different vegetation, widespread across all continents and several islands in the Northern Hemisphere until the end of the Pleistocene.

\section{The end of the Pleistocene - ancient Holocene (Late Paleolithic) - (40 000-10 000 BP)}

At that period the territory of the modern forest zone of Eastern Europe was dominated by wood pasture ecosystems (forest patches were preserved in river valleys) with mammoth complex representatives as keystone species. Firstly, Mammoth (Mammuthus primigenius Blum.) was the largest key species (Fig. 1.), and, in Europe, in second place were woolly rhinoceros (Coelodonta antiquitalis Blum.), prehistoric bison (Bison priscus Boj.) and wild horse (Equus sp.) (Fig. 2).

Populations of large herbivores species of this complex led to suppression of woody vegetation and formation of pasture ecosystems of high productivity [30, 31].

The analysis of radiocarbon dating [32] and data on distribution of key species of plants and animals shows that in the late Pleistocene, during warming and cooling periods, there were stable pasture ecosystems with mixed flora and fauna. The continuity of these ecosystems' dominance throughout the Pleistocene is supported by various authors [18, 19, 28, 33-43].

In the late Wurm (about 110,000 to 12,000 years ago) $[44,45]$ the Pleistocene maximum regression of the oceans, and, respectively, erosion of the terrain (land relief) were accompanied by increased climate continentality (climate with significant annual temperature variation). This increase concurred with the general trend of cooling (primarily in high latitudes) due to the process of orogenesis, which had begun in the Late Mesozoic Era [46].

It should be noted that the maximum roughness in Late Wurm significantly compensated the climate severity increase. Eroded river valleys (130-140 m lower than now) were not only refugia for many species of flora and fauna, but also served as a channel for broader geographical distribution and vertical dispersal of species. Simultaneously, the growing diversity of the land relief was the reason for increasing patchiness of the 
ecosystem cover and increased biodiversity. In addition, the development of the river network significantly enhanced penetration of the southern flora and fauna to the north - and northern species to the south. Predominance of open and semi-open landscapes was one of the reasons for existence of the mixed flora and fauna typical not only for the Late Wurm, but also for prior periods. The main feature of this landscape was the concurrent presence of modern tundra species (arctic foxes and lemmings) and modern steppe species (steppe pikas, steppe marmots, jerboa, hamsters, lemmings, wild horses, saigas, etc.).

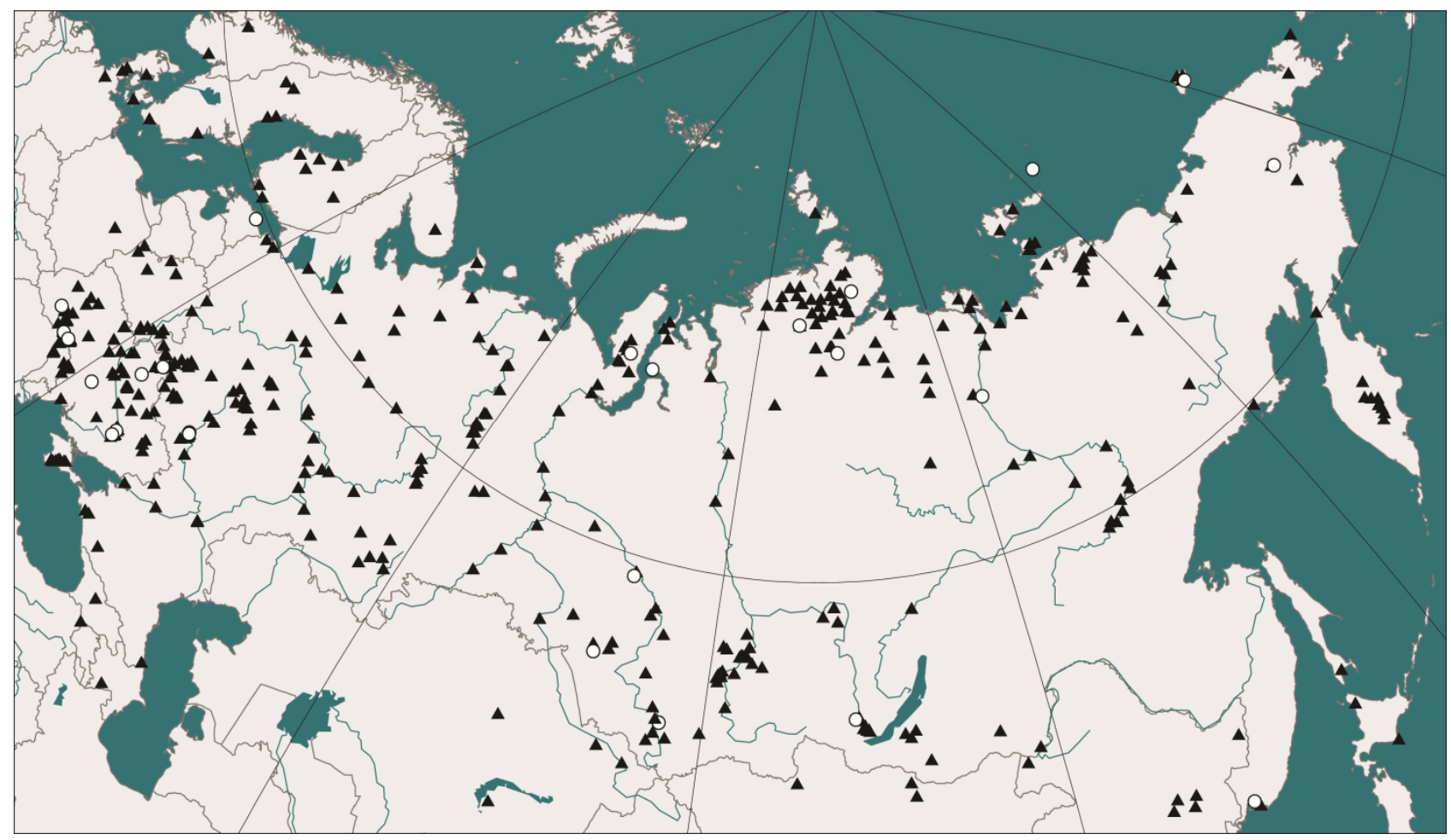

Fig. 1. Distribution of mammoth remains in Late Pleistocene (black triangle) and Holocene (white circle)

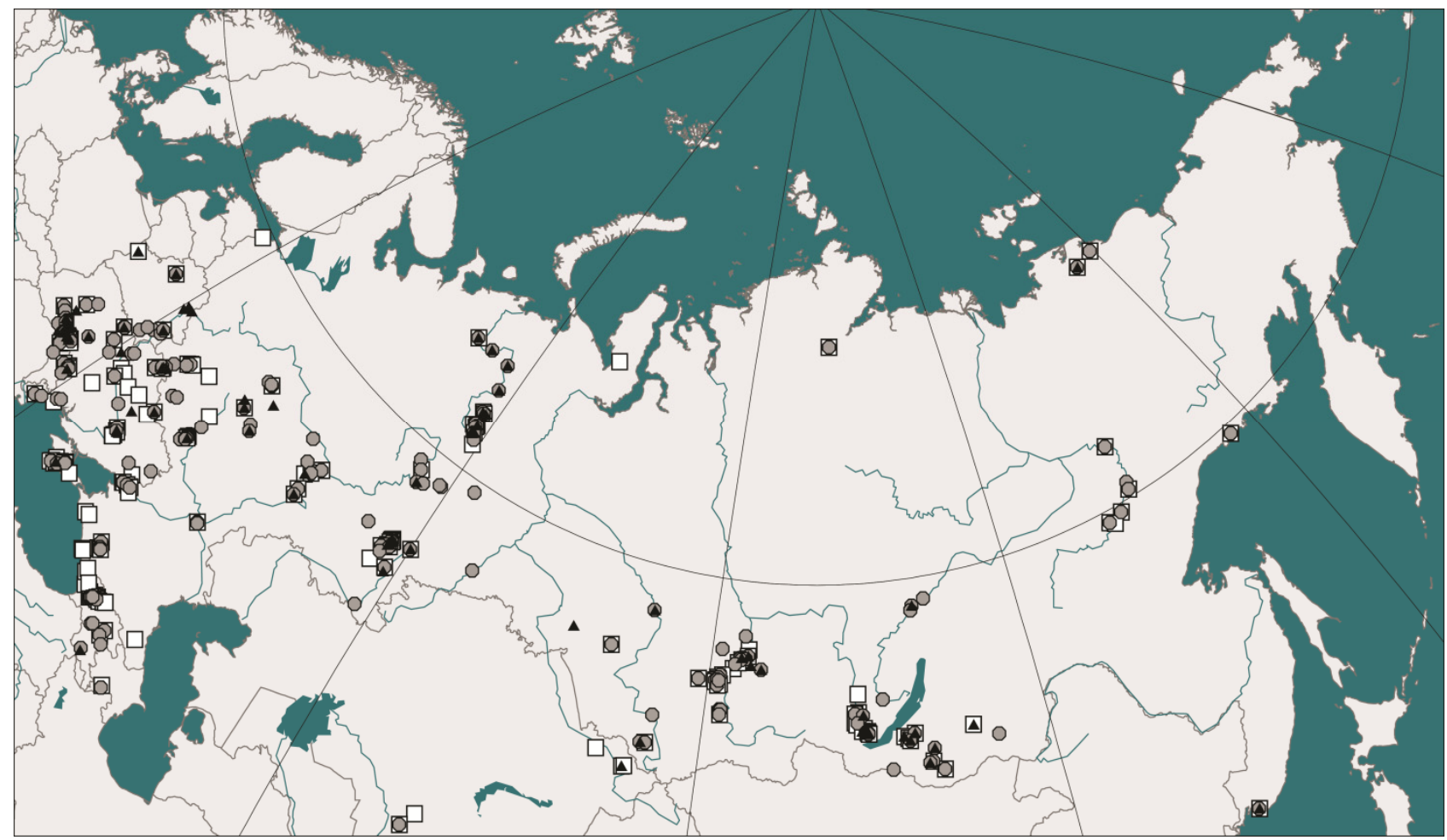

Fig. 2. Distribution of rhinoceros (Coelodonta antiquitalis) (black triangle), prehistoric bison (Bison priscus) (white square) and wild horse (Equus sp.) (greycircle) remainsinPaleolith 
It should be noted that since A. Y. Tugarinov's work in 1929 [47] landscapes of the late Wurm have been attributed to the open type; these were the socalled "tundra-steppe zone" or "periglacial zone". Supporters of the glacial concept followed Gromov [33], suggesting that open landscapes were inhabited mostly by representatives of the "Arctic" fauna, well adapted to the harsh climate of the last glaciation [48-51]. Warming in the Holocene was considered as the main cause of extinction of "arctic" fauna species. However, the gradually accumulated data on the fauna and flora of the Pleistocene and its last period $[28,30,31,34,35,37-40,52]$ indicate its mixed nature. This feature can be satisfactorily explained only in terms of the anti-glacial theory $[18,19,36,43,53-55]$.

Additional ideas about the fauna of open landscapes was gained when the "Zhiguli" cave opened data on the cave fauna, which is far better pre- served than plain fauna [56]. The efforts of many authors $[41,57-75]$ were accumulated in the results that clearly demonstrate the "mixed" composition of terrain fauna (in the upper Pechora basin avifauna also [58]) all over from the lower Pechora River to the South Urals.

This information significantly changes the perception of fauna and the concept of the late Wurm landscapes and specifies terrain fauna changes in the Holocene (Fig. 3, Table 2). In addition, the findings in the caves provided a more complete understanding of the features of Pleistocene landscapes. Thus the findings of a polar bear on the middle Pechora and bird species now confined to a narrow coastal strip of the Arctic Ocean [44] suggest the likelihood of marine transgression (to the north of Eastern Europe - ingression, which flooded mostly river valleys, when the sea level rose).

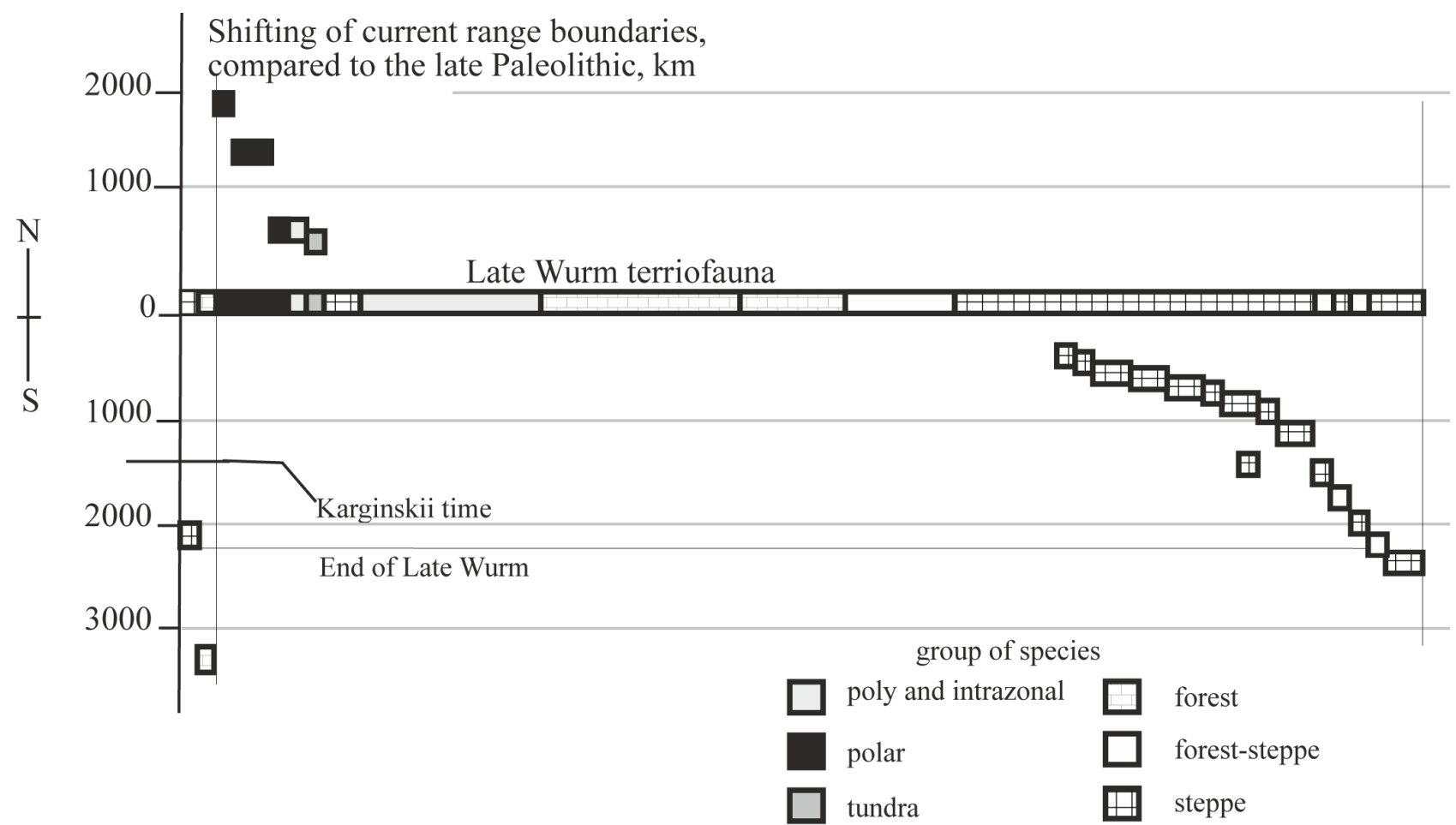

Fig. 3. Changing of structure of terrain fauna in Ural Mountains from Late Wurm up to present

The mixed nature of the fauna of areas, located relatively close to the cold waters, implies that the ingression had no significant impact on the climate (existence of such mixed fauna would be absolutely impossible during the transgression in this area of the Arctic waters of the Arctic Ocean). A similar situation is currently registered on the coast of the Kara Sea, characterized by high ice cover among the seas of the Eurasian sector [76]. However, Siberian larch, Siberian spruce were registered on the pollen analysis and dendrochronological data just $80 \mathrm{~km}$ from the coast on the Hadyta river and its tributaries [77-79], as well as a large set of boreal species of herbs and shrubs [80].

The Mosaic structure (patchiness) provided unique landscapes of the late Wurm with mixed teriofauna, determined by mountain relief diversity and the impact of key species of the mammoth complex. It was during the warming (Karginskii time), when porcupine Vinogradov and Himalayan bear lived together on the border of the Northern and Middle Urals with typical representatives of the mammoth fauna, and also during the coldest period of the late Wurm ("Polar Ural stadial") 
$[75,81]$, when a polar fox and lemmings, a bank vole, a moose, a saiga and a wild horse were found in the Northern Urals together (the Bear's Cave in the upper Pechora) (Table 2).

Table 2

Trends of fossil mammals remains findings in the Urals Mountain, from the late Paleolith to the Present

\begin{tabular}{|c|c|c|c|c|c|c|c|}
\hline Species & Habitats & $\begin{array}{l}\text { Late } \\
\text { Paleolith }\end{array}$ & Mezolith & Neolith & $\begin{array}{c}\text { Bronze } \\
\text { Age }\end{array}$ & $\begin{array}{l}\text { Iron } \\
\text { Age }\end{array}$ & $\begin{array}{l}\text { 20th } \\
\text { cent. }\end{array}$ \\
\hline Vinogradov's porcupine & Mountains, steppe & & & & & & \\
\hline Himalayan bear & Nemoral forest & & & & & & \\
\hline Cave hyena & Steppe & & & & & & \\
\hline Cave lion & Steppe & & & & & & \\
\hline Woolly rhinoceros & Steppe & & & & & & \\
\hline Large cave bear & Steppe & & & & & & \\
\hline Cave bear & Steppe & & & & & & \\
\hline Mammoth & Forest-steppe & & & & & & \\
\hline Saiga & Steppe & & $?$ & & & & \\
\hline Muskox & Steppe & & $?$ & & & & \\
\hline Wild horse & Steppe & & $?$ & & & & \\
\hline Polar fox & Tundra & & $?$ & & & & \\
\hline Hare & Forest-steppe & & $?$ & & & & \\
\hline Marmot & Steppe & & $?$ & & & & \\
\hline Long-eared jerboa & Steppe & & $?$ & & & & \\
\hline Lepus & Steppe & & $?$ & & & & \\
\hline Eversmann's hamster & Steppe & & $?$ & & & & \\
\hline Arctic lemming & Tundra & & $?$ & & & & \\
\hline Siberian brown lemming & Tundra & & $?$ & & & & \\
\hline Irish elk & Forest-steppe & & & $?$ & & & \\
\hline Ground squirrel & Steppe & & & & $?$ & & \\
\hline Aurochs & Forest-steppe & & & & & $?$ & \\
\hline Bizon & Steppe & & & & & $?$ & \\
\hline Yellow lemming & Steppe & & & & & $?$ & \\
\hline Steppe lemming & Steppe & & & & & $?$ & \\
\hline Steppe polecat & Steppe & & & & & $?$ & \\
\hline Steppe pika & Steppe & & & & & $?$ & \\
\hline Gray dwarf hamster & Steppe & & & & & $?$ & \\
\hline Northern mole vole & Steppe & & & & & $?$ & \\
\hline Narrow-headed vole & Steppe & & & & & & \\
\hline Red deer & Forest-steppe & & & & & & \\
\hline Roe deer & Forest-steppe & & & & & & \\
\hline Elk & Forest & & & & & & \\
\hline Raindeer & Ubiquitous & & & & & & \\
\hline Wolf & Ubiquitous & & & & & & \\
\hline Fox & Ubiquitous & & & & & & \\
\hline Braun bear & Forest & & & & & & \\
\hline Stoat & Ubiquitous & & & & & & \\
\hline Least weasel & Ubiquitous & & & & & & \\
\hline European mink & Ubiquitous & & & & & & \\
\hline European pine marten & Forest & & & & & & \\
\hline Sable & Boreal forest & & & & & & \\
\hline Wolverine & Ubiquitous & & & & & & \\
\hline Badger & Ubiquitous & & & & & & \\
\hline Otter & Ubiquitous & & & & & & \\
\hline Lynx & Forest & & & & & & \\
\hline Squirrel & Forest & & & & & & \\
\hline Beaver & Forest & & & & & & \\
\hline Mole & Nemoral forest & $?$ & & & & & \\
\hline Boar & Nemoral forest & & & & $?$ & & \\
\hline
\end{tabular}

The analysis of paleodata from Eastern Europe suggests that in periods of cooling an adverse im- pact of climate change and increased pressure of mammoth herbivores on vegetation led to reduction 
of tree species abundance and their survival in refugia only (in overdeepened river valleys). During warming periods tree species disseminated at surrounding areas. That is why broad-leaved and coniferous tree species with different abundance resided together until the end of the Pleistocene, otherwise the forest cover was mixed [23, 38, 40, 82, 83].

Maps of deciduous and conifer tree species complexes for that period show absence of forest zones (Fig. 4).

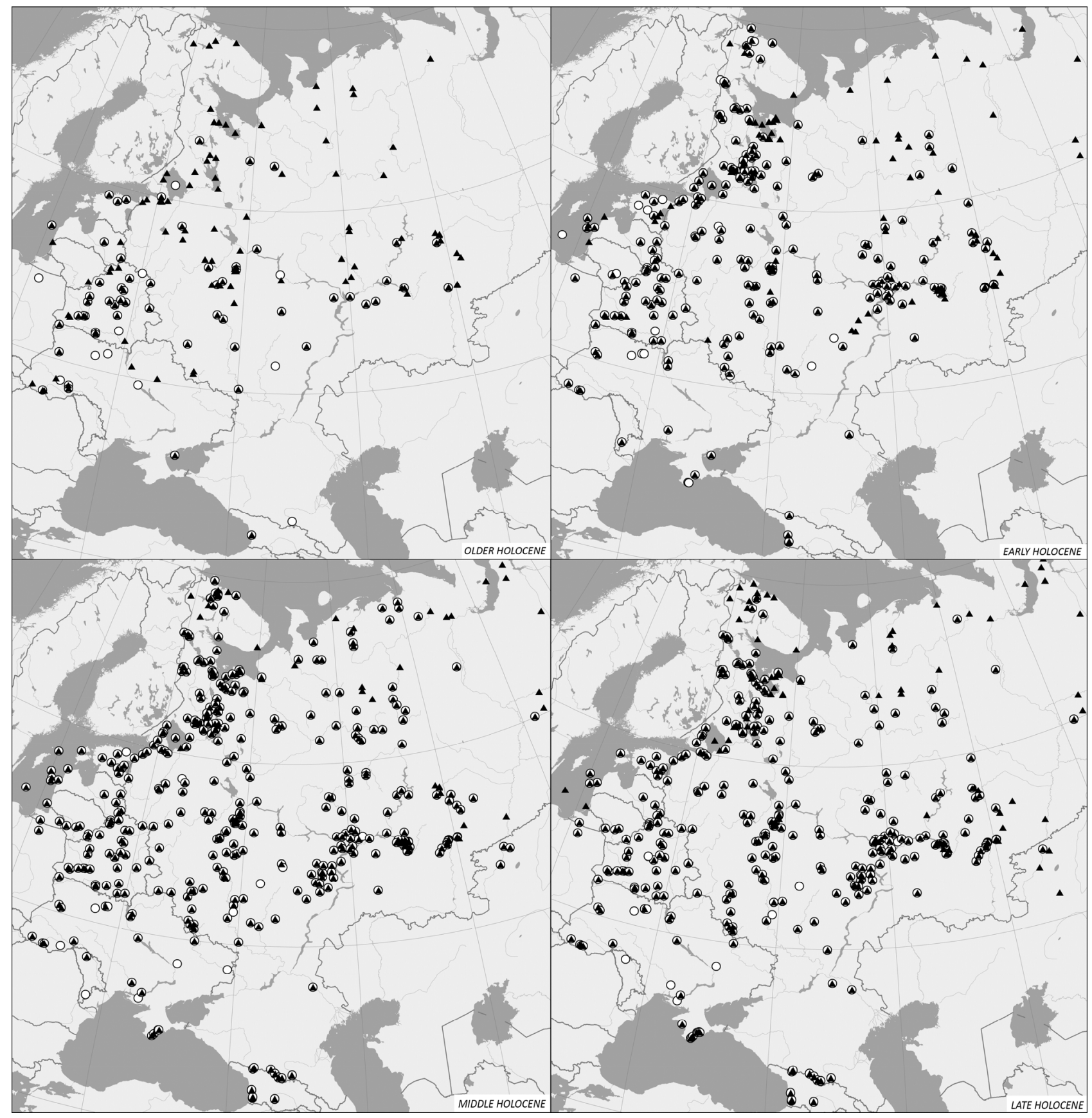

Fig. 4. Distribution of boreal complex tree species (black triangle) and nemoral complex tree species (white circle) in Older, Early, Middle and Late Holocene

Based on paleontological data and specifics of fauna and flora, the vegetation cover of the discussed period can be considered a mosaic of forests, meadows and steppes. Moreover, dominance of pasture ecosystems was due not only to unfavorable climatic conditions for tree species (low temperatures), but mainly to suppression of woody vegetation by large herbivores of the mammoth fauna.
The population of mammoth complex key species and the mammoth itself became critical as a result of hunting activities in the end of the Pleistocene [30, 34, 84-87]. The mammoth either disappeared or its quantity was not enough to remain a key species at the most part of its area. It was shown by the data from early man sites, where fossils of dominant herd ungulates [88, 89] replaced previously dominated mammoth remains. 
Besides, mammoth, woolly rhinoceros, cave lion and hyena, large and small cave bear $[32,66,90]$ became extinct by the end of the late Wurm and early Holocene in Eastern Europe. Northern borders of saiga and red deer habitats moved down to the south $[65,70]$. Giant deer became extinct about 7000 BP in Ural mountains [91].

Extinction, shrinkage of the habitat of large herbivores of the mammoth complex resulted in spreading woody vegetation and reduction of areas of grass (pasture) ecosystem, which favored a slight warming [92]. The pioneers of afforestation were highly volatile tree species with seeds and fast turnover of generations: willow, birch, aspen and European pine. The pollen spectra of this period is marked by dominance of pine and birch [93, 94].

At the end of the Pleistocene replacement of grassland ecosystems by forests was initiated by primitive hunters who made a decisive contribution to reduction of area and population, and then extinction of mammoth and associated species: cave lion (Leo leospelaea), cave bear, cave hyena, giant deer, musk ox (Ovibos moschatus), prehistoric bison and woolly rhinoceros [19].

Later, at the late Pleistocene and in the beginning of the Holocene, the ocean transgression and the sea level rising lessened climate continentality. Most likely, the decline in population and composition of key species led to replacement of pasture ecosystems by forest ecosystems that began an irreversible process. Of course, it is particularly important in regional climate conditions. In the Far North, pasture ecosystems were gradually replaced by the tundra ecosystem, but the process took a very long time since the last mammoths became extinct about $3000 \mathrm{BP}$ on Wrangel Island; and reindeer have survived to the present time on Arctic islands, and the musk ox - on North American Arctic islands. In a warmer and humid climate, these wood-pasture ecosystems were replaced by forest (including boreal) ecosystems. In the middle zone of Eastern Europe, including the territory of today's Moscow region, a number of species that were part of the pasture ecosystems was saved until the end, or almost to the end of the Holocene (more below).

The environmental change on vast territories caused the corresponding climate change. As a result, intensive replacement of the open steppes by wood vegetation dramatically reduced activity of summer anticyclones.

This has contributed to an increase in rainfall and water content, which in turn has proved to be very favorable for an increase in beaver population, which in return has enhanced water-irrigation processes. As a result, these replacements appeared to be more important than the activity of primitive hunter-gatherers, the pasture type ecosystem was transformed, the northern allocation of steppe species pushed to the south and south-east.

Thus, since the end of the Late Pleistocene it began the process of change of keystone species (change of edificators - [87]): Giants and large herbivores species of mammoth complex stepped down a position of key species to tree species of modern forest zone. As a result of the slow start (which is quite natural in a fairly harsh climate), but steady replacement of pasture ecosystems for forest (detrital).

\section{The early Holocene - Mesolithic (10 000-7000 BP) and the middle Holocene - Neolithic and the Bronze Age (7000-2500 BP)}

The beginning of this period was characterized by a noticeable warming along with periodic cooling and warming $[59,92]$. Pasture ecosystems continued to transform into detrital ecosystems due to the mammoth complex giants and large herbivores elimination. The intensity of this process was positively correlated with climate severity and humidity.

There are no data on the mammoth fauna presence to the East of the White Sea (the north of Eastern Europe) during the Holocene (except for survived brown bear, elk and reindeer), but to the west and to the south of their former area they survived in the Holocene as well.

At the beginning of the Holocene mammoths still persisted in the north-west of the Russian Plain (in Baltic region, Vologda region, Karelia and the Kola Peninsula), and in some places on the peripheral areas of its giant area in the recent past they lived even longer: up to 7000 BP (the Yamal peninsula), to 3700 BP (Wrangell island) [66, 95-97]. Aurochs (Bos primigenius) were known up to the middle Holocene in the Lake Ladoga area [98], and in the regions to the south (or at least most of them) a set of species were found: wild horses, wild boars, giant deer, red deer and reindeer, deer, aurochs, bisons, saigas and musk oxen - were present throughout the early or even mid-Holocene [61, 62, 65, 99-106].

Among ungulates inhabiting the forests, wild boar expanded its area to the north and elk became more numerous in the Russian Plain, but disappeared from the Caucasus $[107,108]$. Several species (wild horses, deer, elks, reindeer, aurochs) as well as mammoths penetrated to the north-west of Eastern Europe up to the Kola Peninsula in the early Holocene after degradation of the White SeaBaltic Sea basin almost to its present size.

This opened opportunities of invasion to Fennoscandia from the East for mammoths, musk oxen, reindeer and elks (species that lived in the 
western part of this territory already in the late Pleistocene) $[109,110]$.

One cannot ignore that the destruction of the Paleolithic mammoth hunters' mode of life lead to a long environmental crisis for the population of Europe (and Eurasia as a whole): the number and density of Mesolithic sites drastically reduced [88, 89, 111].

That crisis was overcome only in the Neolithic period [112], when the spread of the producing economy (agriculture and animal domestication originated in more southern areas) effectively changed the very nature of human impacts on natural ecosystems. It should be taken into account that the extent of that impact increased gradually. That is why a number of species that were part of the Pleistocene mammoth fauna were preserved on the analyzed territory until the middle or even the late Holocene.

The process of transformation of pasture ecosystems by closed forest ecosystems was started by pioneer species (pine, aspen etc.) characterized by relatively fast expansion $[39,52]$, later replaced by key species of dark coniferous and broad-leaved trees (spruce, fir, oak, beach etc.). Changes in the ratio of steppe-pasture and forest communities in favor of the latter initiated formation of forests on the major part of Eastern Europe except for the northern territories (the Ugra Peninsula, Kolguev island, Vaigach island and South island of Novaya Zemlya) occupied by tundra and forest tundra.

This process in turn helped increasing the number of forest animals: squirrel, beaver, brown bear, wild boar, elk and other ungulates that benefited from expansion of forests. In the early Holocene, as in the previous period, forests were mixed, combining conifers (spruce, fir) and broad-leaved (oak, linden, elm, and other) tree species almost on the entire territory (Fig. 4) [10, 23].

Later in the middle Holocene almost the entire territory of Eastern Europe was a mosaic of meadow-steppe and forest (coniferous and broadleaved) zone with the meadow steppe formed by large herd herbivores, alternated with forested areas. There was no clear division into the taiga and deciduous forests; instead, there was a gradual decrease in the proportion of species of deciduous trees from the south to the north and the proportion of species of conifer trees in the opposite direction. Large herd herbivores: elk and reindeer, along with wild boar, red deer, deer, auroch, bison and wild horse, and sometimes saiga and marmot, coexisted in the southern part of the forming forest zone before the Iron Age till the Middle Ages, as proved by the osteological data. This allows us to reconstruct the ecosystem cover of this time as a mosaic of forest patches, alternated with meadow and steppe areas of zoogenic origin [10].

Existence of grassland and forest communities and ecotones between them allowed sustainable existence of the key species of light-demanding trees such as oak, pine, Siberian larch. They were accompanied by subordinate light-demanding species of trees, bushes, dwarf shrubs and grasses.

At the same time fossil remains of beavers were found on the major part of the Eastern Europe forest zone [10]. It indicates that widespread water communities were formed due to beaver's construction activities. Beaver ponds on numerous streams and small rivers allowed existence of various animals, plants and other species in so-called "beaver landscapes". Widespread hydromorphic landscapes determined a high level of soil and air moisture [113]. Apparently this was one of the major reasons of spreading of dark coniferous species (spruce and fir) to the south and broad-leaved species to the north, embracing one meadow-steppeforest (coniferous - broad-leaved) zone. In addition, prevalence of hydromorphic landscapes prevented the spread of fires. Subsequent differentiation of the meadow-steppe-forest (coniferous and broad-leaved) zone led to formation of the boreal (taiga) zone.

Thus, from the late Pleistocene to around middle Holocene, mainly due to destruction of key species of the mammoth complex, there was a significant transformation of the ecosystem cover of Eastern Europe: pasture ecosystems were replaced by detrital and pasture ecosystems with equal shares.

Producing economy (agriculture, cattle breeding and metal smelting) development in the middle Holocene became a powerful factor influencing the ecosystem cover (the Neolithic Revolution). It spread in Eastern Europe 6000-5500 BP and dominated on most of its territory during the Bronze Age (4600-3200 BP). The share of fossils of wild hoofed animals (bison, auroch, wild horse, etc.) reduced, while the share of livestock bones increased $[99,100]$, also the pollen analysis showed the presence of domesticated cereals and weeds [114-116], as proved by the osteological material.

Producing economy fundamentally changed the structure of the ecosystem cover. First of all, large herd ungulates and beavers disappeared mostly not because of direct persecution, but due to habitats transformation for producing purposes. Destruction of large ungulates resulted in disappearance of meadows and ecotones, essential for lightrequiring tree species, all other light-demanding plant species and many animal species. The economic activity determined existence of key species directly (trees planting) or indirectly (plowing, 
burning, grazing in forests, drainages, pond constructions, etc.). Only shade-tolerant tree species (deciduous trees, except oak species, spruce, cedar and fir), shade-tolerant bushes, shrubs, herbs and mosses were able to maintain a steady generation turnover without human assistance in such environment. Ecosystems of "shadow" coniferousbroad-leaved forests were formed, which nowadays have survived only in a small number of refugia in European Russia, in habitats not affected by significant anthropogenic transformations of the last few centuries and, therefore, mistakenly taken for natural forests $[10,12]$. By the end of the middle Holocene slash-and-burn agriculture notably pushed the southern border of the forest zone to the north.

Elimination of beavers harshly reduced natural diversity of valley landscapes of small rivers and streams, affected the hydrological regime stability, previously supported by dams and beaver ponds. At the same time, this led to a fire danger increase in forests.

In the late Middle Holocene, expansion of nomadic cattle breeding in the south of Eastern Europe led to formation of steppe and semi-steppe zones, increased climate aridity and reduced the mixed character of flora and fauna. These were major steps in formation of modern zoning, including the boreal (taiga) zone, and had significant impact on macroclimate changes in Eurasia as a whole. Perhaps these were among the reasons of a climate instability increase in the second half of the Holocene [50, 92, 117, 118].

\section{The Late Holocene (2500-0 BP) - The Iron Age and Middle Ages (2500-500 BP)}

Habitats of key species of trees did not change significantly at the beginning of the late Holocene in the early Iron Age (2500-1600 BP), as the palaeobotanical analysis shows. Broad-leaved and coniferous species coexisted on the major part of the forest zone just as in the Middle Holocene (Fig. 4). However, the quantitative assessment of the pollen share of different tree species in the pollen spectra showed a decline of the dark coniferous species share in the south and the broad-leaved share in the north [93, 94, 119-121], and an increase of pollen of Pinus sylvestris led to increased fire activity. This process was due not only to expansion of the steppe zone to the north and increased soil and air dryness because of anthropogenic aridization in the south of Eastern Europe, but also due to direct anthropogenic impacts. The most significant were the following: usage of oak for shipbuilding [119] and for industrial production of wood charcoal since the beginning of XVIII century [122], and massive logging for a variety of other purposes [10].

At the same time, mainly as a result of slashand-burn agriculture, the northern borders of broad-leaved tree species areas significantly retreated to the south. That marked formation of the modern taiga - a boreal forest zone, where broadleaved tree species are absent. At the same time, specific pyrogenic forests with dominance of Scots pines were formed [123] on vast territories with sandy soils. Slash-and-burn agriculture followed by swidden and arable farming, grazing in the forest, collecting of litter and deadwood and other traditional forest management practices led to soil cover degradation on vast areas $[15,16]$. Forest burning on its northern borders led to tundra expansion over the northern taiga and the forest tundra in the late Holocene [124, 125]. Anthropogenic factors and climate changes of the late Holocene acted concurrently in the north of the forest zone. These led to destruction (purification) of the forest zone and fostered expansion of boreal species and their complexes. This process is called "borealization" of the forest zone.

Despite the fact that human impacts on natural ecosystems and their components steadily increased and became more diverse during the Neolithic and the Bronze Age, yet some areas remained underdeveloped. Therefore, such species as musk ox (Scythian drawings, see: [104, 126]) and onager (Equus hemionus) lived in the southern steppes and Ural, wild horse lived in the Caspian region [127] up to the Iron Age. Wild auroch, bison and tarpan - wild horse [101, 102, 106, 128] still exist in the south of the modern forest zone. The tarpan remains were found on the territory of modern Moscow at the beginning of the Iron Age (completely exterminated in the XIX century) as well as wild boar, red deer and reindeer, roe deer [103]. Reindeer were spread more to the south, comparing to its actual area $[99,122,129]$.

Commercial fur trade, primarily in beaver and sable, emerged at the beginning of the Iron Age, and, incidentally, hunting pressure on larger ("meat") animals - elk and bear - sharply increased. This was observed during the research of massive osteological materials, obtained while excavating Dyakov settlement (south of Moscow). The people of this settlement switched from natural economy in the early Iron Age (2500-1500 BP) over to commercial hunting in 300-200 BP. The composition of prey species changed as a result: tarpan, red deer, raindeer, roe deer completely disappeared, a little later - wild boar, too. Hunting for beavers, elks and brown bears dramatically increased according to the analyzed remains $[18,103]$. 
Naturally this process developed unevenly in different regions of Eastern Europe. Despite its huge area equaling almost to the entire Palearctic, beavers were exterminated everywhere, including the most remote regions of Eastern Siberia by the late Middle Ages [130].

Thus, the changes in tree species and fauna composition in the Late Holocene which started in the Middle Holocene led to a split of the united steppe-meadow-forest (coniferous and broadleaved) zone into two fundamentally different community groups [131]:

(1) communities, capable of supporting itself developing spontaneously ("shadow" forests), that formed the forest zone as is, and (2) communities, requiring permanent anthropogenic impacts for maintenance (floodplain and upland meadows, meadow steppes, forest of light-requiring tree species: birch, scotch pine, larch, oak).

The traditional economy was evolving over a long time and in some forms was similar to natural processes (e.g. livestock grazing in the forest, construction of dams on small rivers for mills, etc.), so it helped supporting the ecosystem cover's heterogeneity.

However, at that point of time, the final step in formation of the modern zoning was made: a split of the forest zone of Eastern Europe into dark coniferous (boreal), coniferous and broad-leaved (boreal-nemoral) and broad-leaved (nemoral) forests, caused by anthropogenic impacts.

\section{The Modern time (500 BP)}

In recent centuries (since 18th, but especially in 19th and 20th centuries) further transformation of the ecosystem cover of Eastern Europe has been driven by land-use change and industrial development [10]. At that time, such species as auroch, bison, tarpan disappeared; areas of all large mammals, beaver and others decreased. Populations of some species have been restored during last decades: the beaver population has been restored due to restoration activities and further spontaneous dissemination, populations of wild boar and roe deer have been restored mostly due to urbanization and consequential land abandonment in rural areas.

Due to intensive agricultural development and timber harvesting, nemoral (broad-leaved) and nemoral-boreal (mixed broad-leaved and coniferous) forests have virtually merged into a single zone [132]. Small-leaved forests on clay soils and planted pine forests on sandy soils have alternated with agricultural lands. At the same time, forests with key species dominance have covered small areas [10].
However, oak was registered in the lower part of the Northern Dvina river even before the beginning of the 18th century [120]; hornbeam was registered to the north up to Valdai lowland [119] and elm was registered up to Obdorsk (now the town of Salekhard) [121] till the end of the 18th century.

The boreal (taiga) forest zone finally became isolated inside the forest zone due to multiple human-induced fires, rural land abandonment because of inefficiency of agricultural activities and a population decrease. A mosaic of pyrogenic and weed grassland communities of different ages from young pine stands and birch forests to spruce and spruce-fir forests was formed. A substantial part of grassland ecosystems, supported in boreal forests by human activities since the middle - late middle Holocene, disappeared during the last one or two centuries due to land-use changes (agricultural activities including a livestock grazing decrease) and a catastrophic decline of rural population.

Most of the modern taiga forest ecosystems are at the early succession stages with pioneer species of trees (pine, birch) or the first generation of latesuccession trees (spruce, more rarely fir) and minimal species. The latter are spruce and spruce-fir forests of green moss, green moss with dwarf shrubs and small boreal herbs (Oxalis acetosella).

These most widespread types of East European dark coniferous forests $[20,133]$ were formed and supported by human activities [10], and, unfortunately, are often seen as natural forests.

However, the analysis of modern distribution of nemoral and boreal shrubs and herbs, as well as presence of ephemeroids in the refugium [80] indicates that the original type of modern boreal forests is boreal-nemoral forests (Fig. 5).

It is in contemporary history, when such species as auroch, bison, tarpan disappeared, and areas of all large mammals, beaver and some other species decreased (populations of some species have been restored during last decades due to restoration activities).

The main trends of teriofauna transformation since the late Wurm to the present are the following:

1. Loss of habitats for many species (primarily, the largest and most actively hunted animals);

2. Extinction of some animal species (totally or within the Palearctic);

3. The single fauna was split up in space into faunas of tundra, forests and steppes. It is significant that the extinction rate of the Pleistocene theriofauna species was exponential, continuing at the present time (Fig. 6). This process will continue for a long term, unless appropriate and extraordinary measures are taken, as proved by the available data [134]. 


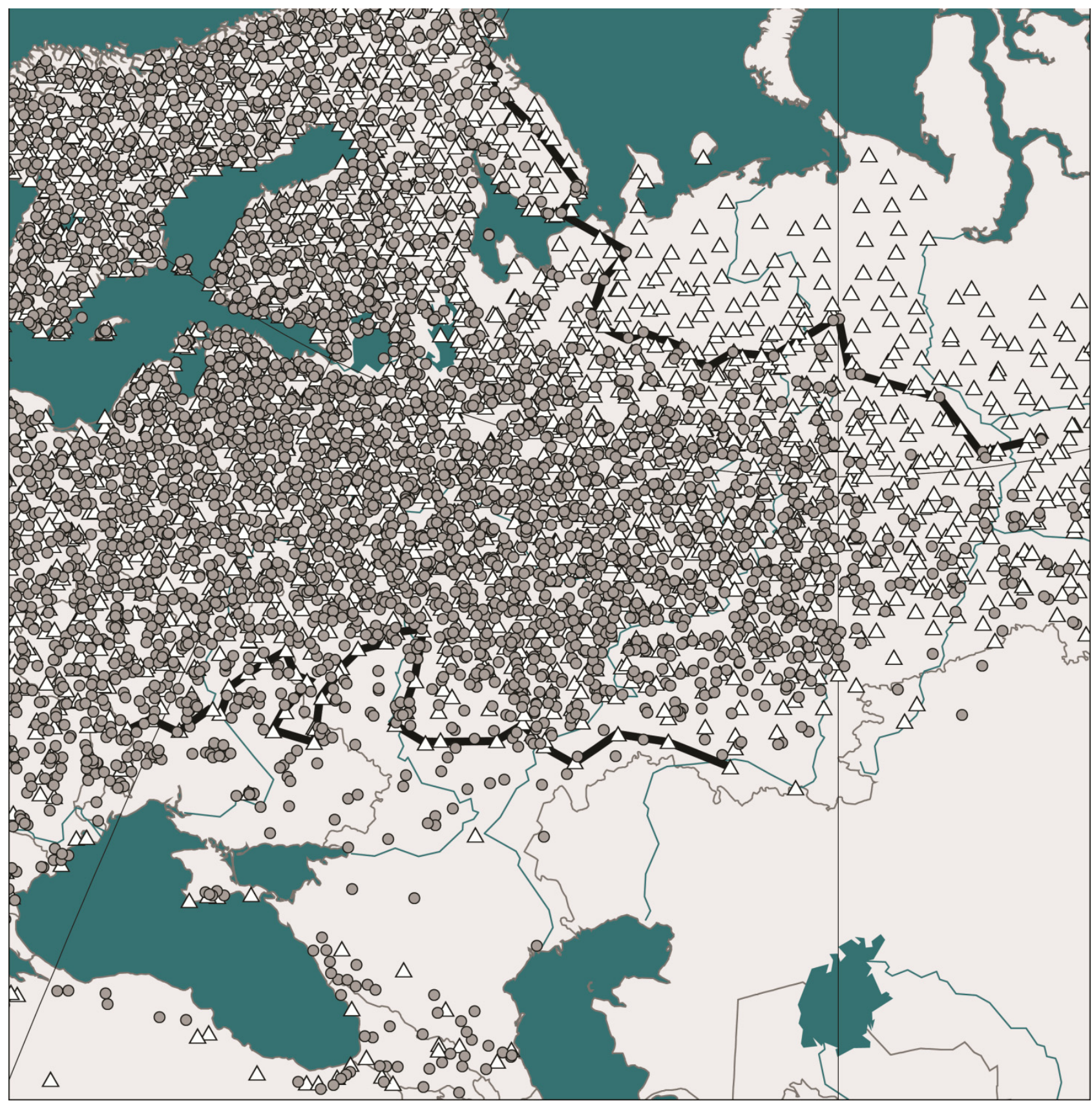

Fig. 5. Modern distribution of boreal and nemoral complex of grass and shrubs (Lipmaa, 1938)

(boreal - white triangle, nemoral - grey circle). The upper line shows north border of nemoral grass species, the line on the south shows border of boreal grass and shrubs species

The proposed model reconstruction shows that the main factor in formation and development of the vegetation cover of Eastern Europe, including boreal forests during the Holocene, was and is human land-use activities. It comes out as follows:

(1) key species areas direct move due to species extermination on some areas,

(2) key species areas indirect move due to ecotopes and local climate changes, primarily aridization in the south of the forest zone and its borealization in the north,

(3) destruction of functional links between key and indicator species, that provided stable digenesis in populations of species of different trophic groups.
The composition and structure of the most wide-spread types of forest communities (including boreal forests with trees' key species dominance) reflect traditional land-use practices, which were common at least during the lifetime of the current trees generation or a bit earlier.

\section{The origin of the modern boreal zone of Eurasia (the Eurasian taiga)}

The analysis of area changes of key species of animals and plants since the late Pleistocene to the present led to the concept of the dominant role of human activity in formation of the modern bo- 
real zone of Eastern Europe. From this perspective it is advisable to refer to the hypothesis of the origin of the Eurasian taiga (boreal forest) in gen- eral. Since the origin of taiga is well studied $[2,3$, $5,6,38,40]$ we confine this list to the most important ones.

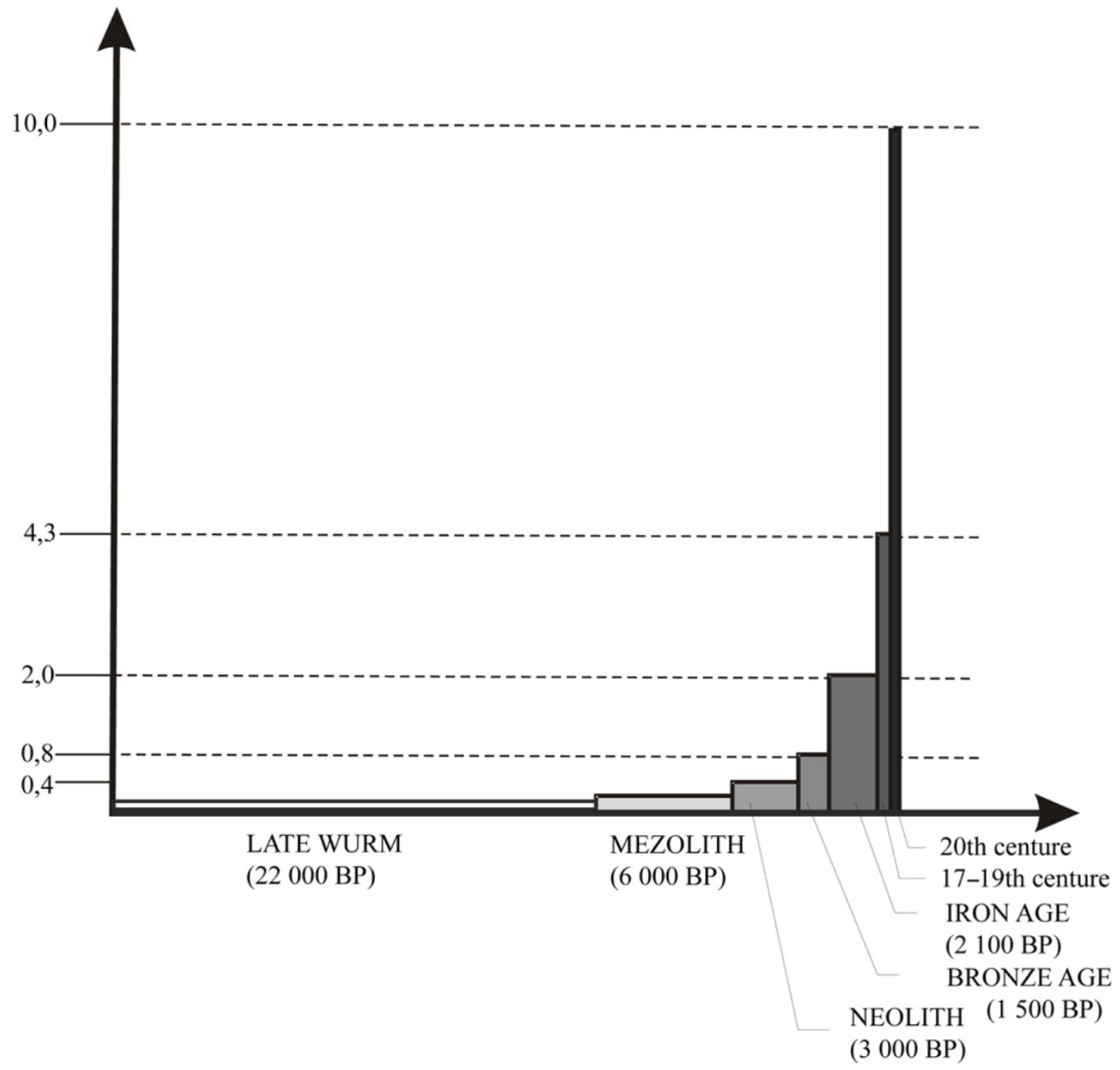

Fig. 6. Extinction rate (number of extinct species during one thousand year) during Pleistocene up to the present

The discussion on the origin of the modern taiga includes the following key issues:

1) what was the initial type of vegetation $[3,5$, $6,27,135]$;

2) does the boreal forest of autochtonous or allochthonic origin have any relation to the current territory of Eurasia and North America?

Neogene forests with rich flora of trees that prevailed on the territory of Northern Eurasia till almost the end of the Pliocene should be considered a natural type according to many authors $[5,38,40,136,137]$. Namely, these forests were the initial condition in formation of the modern forest cover of Northern Eurasia. Generic complexes of broad-leaved and coniferous trees, which compose the modern dendroflora of Northern Eurasia, were founded in Neogene forests.
V. P. Grichuk [40] described the main steps of formation of the modern nemoral and boreal floras from the Neogene flora. These floras were finally formed by the Upper Pleistocene [40]. There was a gradual depletion of generic complexes during the process of formation of the nemoral and boreal floras. For example, V. P. Grichuk allocated 30 generic complexes representing four geographic groups (Table 3 ) in the center of the Russian Plain in the end of the Pliocene. Only 20 of them remained in the Early Pleistocene, 15 in the Middle Pleistocene - and 12 complexes of circum-boreal groups remained in the Holocene. Simultaneously, the number of species in each generic complex significantly reduced. However, the process of dendroflora depletion was gradual, and the mixed nature of dendroflora of the Russian Plain persisted throughout the Pleistocene and most of the Holocene. 
Dendroflora of Late Cenozoic in Vyatsko-Kamsky historical floristic region (Grichyuk, 1989)

\begin{tabular}{|c|c|c|c|c|c|c|}
\hline \multirow{2}{*}{ Group } & \multirow{2}{*}{ Species sp. } & \multirow{2}{*}{$\begin{array}{c}\text { Late } \\
\text { Pliocene }\end{array}$} & \multicolumn{3}{|c|}{ Pleistocene } & \multirow{2}{*}{ Holocene } \\
\hline & & & early & middle & late & \\
\hline \multirow[t]{8}{*}{ Panarctic } & Abies & & & & & \\
\hline & Picea & & & & & \\
\hline & Pinus & & & & & \\
\hline & Betula & & & & & \\
\hline & Alnus & & & & & \\
\hline & Salix & & & & & \\
\hline & Larix & & & & & \\
\hline & Myrica & & - & - & - & - \\
\hline \multirow[t]{10}{*}{ American - North Asian } & Corylus & & & & & \\
\hline & Quercus & & & & & \\
\hline & Ulmus & & & & & \\
\hline & Acer & & & & & \\
\hline & Tilia & & & & & \\
\hline & Carpinus & & & & & - \\
\hline & Ilex & & & - & - & - \\
\hline & Fraxinus & & & & & - \\
\hline & Fagus & & & & - & - \\
\hline & Taxus & & - & - & - & - \\
\hline \multirow{6}{*}{$\begin{array}{l}\text { American - } \\
\text { Mediterranean - Asian }\end{array}$} & Celtis & & - & - & - & - \\
\hline & Pterocaria & & & & - & - \\
\hline & Juglans & & & & $\begin{array}{lll}- & \\
\end{array}$ & $\begin{array}{lll}- & \\
\end{array}$ \\
\hline & Rhus & & & - & - & - \\
\hline & Castanea & & & - & - & - \\
\hline & Ostrya & & - & - & - & - \\
\hline \multirow[t]{6}{*}{ American - East Asian } & Tsuga & & - & - & - & - \\
\hline & Morus & & - & - & - & - \\
\hline & Diervilla & & - & - & - & - \\
\hline & Carya & & - & - & - & - \\
\hline & Chamaecyparis & & - & - & - & - \\
\hline & Liriodendron & & - & - & - & - \\
\hline \multicolumn{2}{|l|}{ Number of genera } & 30 & 20 & 15 & 14 & 12 \\
\hline
\end{tabular}

Given short distances of late succession tree seeds dispersal: from 200 to 1000 meters over the lifetime of one generation $[39,138,139]$, it should be recognized that almost continuous existence of that unique flora was possible only with a sufficient number of closely-spaced refugia, where tree species were preserved during adverse periods in the Pleistocene. The possible existence of refugia and the age thereof were repeatedly discussed in literature $[138,140,141]$. Recently, a valid evidence of refugia allocation in Eastern Europe during the late glacial maximum has been gained, based on the statistically reliable palynological data $[82,83]$. The presence of these refugia determined quick dissemination of key species of trees in the early Holocene.

Recognition of a possibility of continuous transformation of Neogene flora in Northern Eurasia suggests that the taiga (boreal forest) is autoch- thonous in Eurasia and North America, occupied thereby nowadays.

The assumption that taiga is of allochthonous origin, as pointed out by V. B. Sochava [2], is largely determined by the characteristics of the modern taiga, which were considered a result of the genesis of the ancient type of vegetation. If we consider modern pyrogenic dark coniferous forests [9], formed by humans in the Late Holocene, as a model of natural taiga [3], then it is quite difficult to find its origin from the Neogene flora. The hypotheses of its allochthonous origin tried to explain this: the area around the North Pole [135], an ancient land near the Bering Sea [142], the mountains of Palearctic South [3] were considered the original vegetation.

The boreal forest was seen as a younger formation in Circumpolar and Bering hypotheses, and development of the taiga landscape was interpreted as a 
moving of existing species complexes from north to south. In the mountain hypothesis, the taiga was seen as an ancient formation, formed simultaneously with the Neogene vegetation or even earlier. Tolmachev [3] proved the antiquity of the taiga forest by a significant age of boreal herbs species.

Presence of keystone species (similar to Picea sp.) and associated boreal species of herbs and shrubs [3] in Neogene forests make it possible to assume that these mixed (coniferous - deciduous) forests gave place for successful coexistence of boreal and nemoral species. It is confirmed by forest refugia, where ephemeroids and other nemoral herbs species survive under the cover of dark coniferous trees [80].

If coniferous-broad-leaved nemoral-boreal forests of the Far East [2,137] and the Caucasus [1] are considered as natural ones (least disturbed taiga forests), then the hypothesis o fautochthonous origin of the modern taiga from Neogene forests due to gradual climate changes since the late Pliocene to the late Pleistocene is quite legitimate.

Examining the animal population of the late Pliocene allows assuming that the original Neogene mixed coniferous-broad-leaved forests of Northern Eurasia had a structure similar to modern forests.

The analysis of the number of large and very large herbivores (key species of grassland ecosystems) genera, which formed the Palearctic teriofauna since the Pliocene to the present, demonstrates that Neogene forests were inhabited by rich fauna of large and very large mammalian herbivores (Fig. 7).
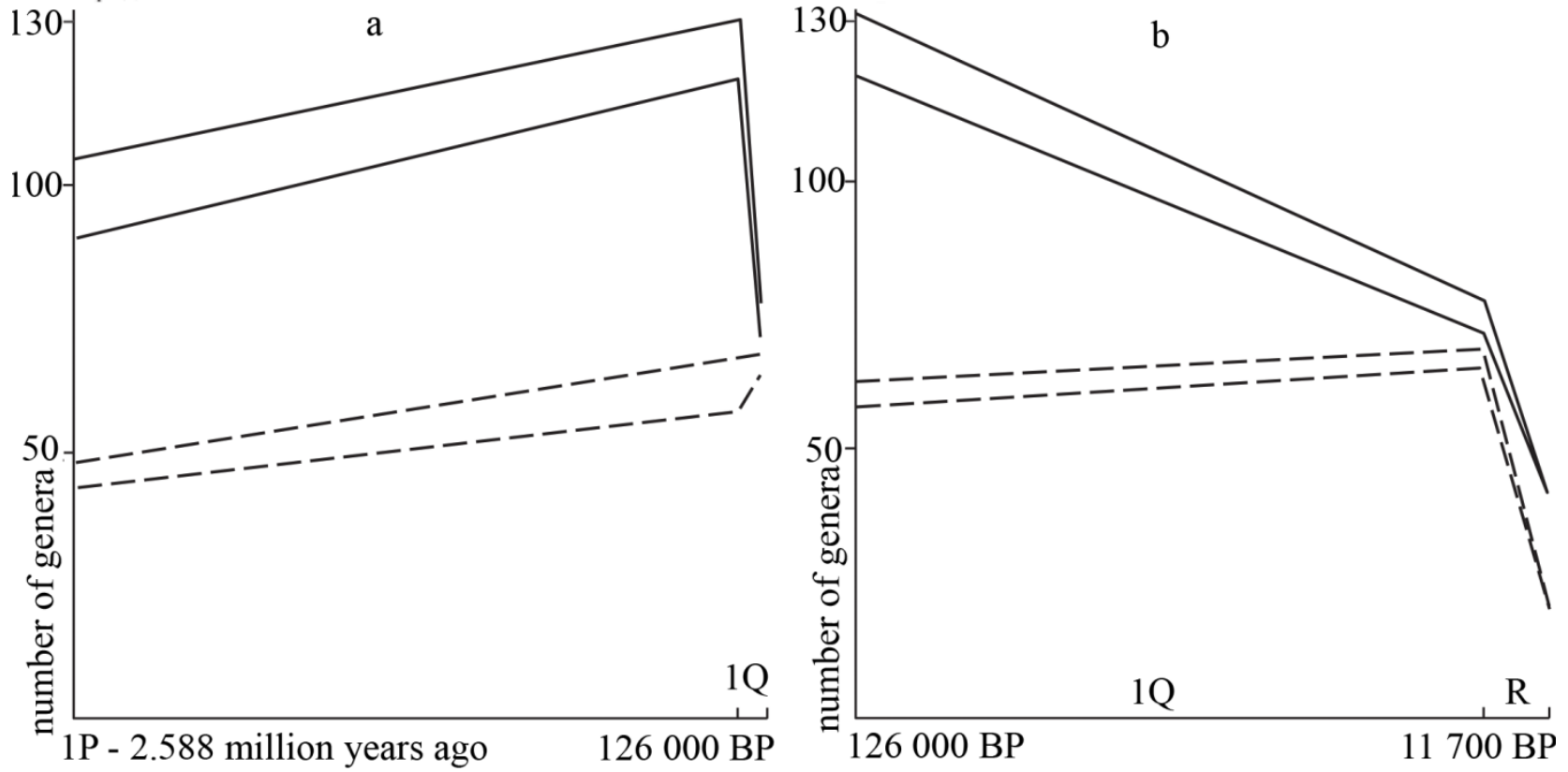

Fig. 7. Dynamics of number of genera from Pliocene up to the present

Most of the genera and species of this fauna inhabited savannas, steppes and forest steppes and many of them were key species of grassland ecosystems. Therefore, the Pliocene landscapes structurally and physiognomically to a greater extent resembled modern African savannas, than modern coniferous-broad-leaved forests of the Far East. Transformation of this fauna from the Pliocene to the present had a clear tendency to exhaustion: 37 genera inside and 24 genera outside the Palearctic survived out of 195 genera (mostly Proboscidea and Ungulates). Moreover, the extinction rate increased exponentially during the Holocene.

For grassland ecosystems the loss of the role of key species by large and giant herbivores was a crucial step in the irreversible transformation of fauna since the final Paleolithic to the late Holocene (in various regions the crisis was in different time, in African savannas it happened only over a century ago). Firstly, it was due to species extermination and consequential reduction of its abundance below the critical level of sustainable generation turnover in populations. After that, further transformation of grassland ecosystems became autogenetic, its effects have amplified exponentially in the modern time and have been intensified by a variety of anthropogenic factors. Thus, the debate about the origin of the modern Eurasian taiga (boreal forest zone) switched into the study of the history of conversion of Neogene savanna forests by human activities.

The analysis of the dynamics of tree key species' paleoareas and data on the composition and structure of the modern remnants of boreal forests $[80,143]$ show that the coniferous-broad-leaved forest zone without the modern boreal forests (tai- 
ga) zone could cover the major part of Eastern Europe (supposing only the climate-caused changes of Neogene forests). The anthropogenic factor since the late Pleistocene to the present, as the most powerful factor at different scales (from local to global) has determined formation of the boreal forest zone, consisting of succession communities, the composition and structure of which reflect different types of human activities over the last centuries.

The image of the modern taiga is very different from the reconstructed image of Neogene forests and their derivatives in the Far East and the Caucasus, so it is impossible to consider development stages of a single vegetation type (or single biome) without analyzing anthropogenic changes. This fact apparently fostered the hypothesis of taiga's allochthonous origin.

Paleobiological reconstruction of the teriofauna and denroflora since the late Pliocene to the present allows assuming that the initial vegetation type for boreal forests was Pliocene coniferousbroad-leaved savanna-looking forests of Northern Eurasia, where large herbivores affected biota the most. The ratio between key tree and animal species shows its fundamental difference from modern coniferous-broad-leaved forests of the Far East, which previously were seen as the Eurasian boreal forests (the Eurasian taiga) origin.

\section{Conclusion}

This study allows to offer a sequence of formation and development stages of the Eastern European taiga (boreal forest):
1. The original type - mixed coniferous-broadleaved savanna-looking forests of Northern Eurasia with rich dendroflora (over 30 generic complexes on the Russian Plain) and rich megafauna (around 100 genera), which included forest and grassland ecosystems (the Pliocene).

2. Refugia of periodically impoverishing coniferous-broad-leaved forests in the forest-meadowsteppe vegetation cover were regulated by giant species of the mammoth complex (the Pleistocene).

3. The meadow/coniferous-broad-leaved forest vegetation was regulated by large herd ungulates, beavers and trees (the Middle Holocene).

4. The forest vegetation split into boreal (taiga), nemoral-boreal and nemoral zones as a result of human activities. Formation of the modern boundaries of the taiga and development of the taiga ecosystems preserved in refugia (first half of the Late Holocene).

5. The anthropogenically caused image of the modern East European taiga is a dominating complex of light and dark coniferous successional communities. Despite a wide distribution, these forests are characterized by their internal imbalances: very poor species composition of plants and animals, monodominant, with tendency for destruction by insects and fungi.

\section{Financial support}

Investigations were partially supported by the RFBR grant 16-16-04-00395

\section{References}

1. Leskov A. I. Principles of the natural system of plant associations. Botanical journal of USSR. 1943, no. 2, pp. 37-46.

2. Sochava V. B. Problems of florogenesis and philocoenogenesis of the Manchurian mixed forest. Materials on the history of flora and vegetation of USSR. Moscow; Leningrad: Publishing of AS USSR, 1946, issue 2, pp. 283-320.

3. Tolmachev A. I. On the history of origin and development of the dark coniferous taiga. Moscow; Leningrad: Publishing of AS USSR, 1954, $155 \mathrm{p}$.

4. Anti T., Hämet-Anti L., Jalas J. Vegetation zones and their section in northwestern Europe. Ann. Bot. Fenn. 1968, vol. 5, pp. 69-211.

5. Yurtsev B. A. Problems of the dark coniferous taiga origin in view of new paleobotanic research. Botanical journal. 1972, vol. 57, no. 11, pp. 1455-1469.

6. Prilepsky N. G. Problem of the taiga origin. On the history of the problem. Botanical journal. 1993, vol. 78, no. 8, pp. 1-16.

7. Smirnova O. V. Population organization of biocenotic cover of forest landscapes. Progress of modern biology. 1998, no. 2, pp. 25-39.

8. Smirnova O. V., Kalyakin V. N., Turubanova S. A., Bobrovskii M. V. Modern zoning of Eastern Europe as a result of transformation of the late-pleistocene complex of key species. The mammoth and its environment: 200 years of research. Moscow: Geos, 2001, pp. 200-208.

9. Smirnova O. V., Kalyakin V. N., Turubanova S. A., Bakun E. Y. Genesis of the Eastern European taiga in the Holocene. Regularities of secular dynamics of biogeocenoses. XXI reading in the memory of academician V. N. Sukachev. Moscow: KMK, 2006, pp. 18-65.

10. Eastern European forests: history in the Holocene and modern times. Edited by O. V. Smirnova. Moscow: Science, 2004, bk. 1, 479 p.; bk. 2, 575 p.

11. The ecological history of European forest. 1998. Ed. by K. Kirby, C. Watkins. Cambridge: Cambridge University Press. 384 p. 
12. Eastern European broad-leaved forests. Edited by O. V. Smirnova. Moscow: Science, 1994, 364 p.

13. Vera F. W. M. Grazing ecology and forest history. Oxon; New York: CABI Publishing, 2000, 506 p.

14. Vera F. W. M., Bakker E., Olff H. Large herbivores: missing partners of western European light-demanding tree and shrub species? Large herbivore ecology, ecosystem dynamics and conservation. Biology series. Ed. by K. Danell, P. Duncan, R. Bergstrom, J. Pastor. Cambridge: Cambridge University Press, 2006, pp. $203-231$.

15. Bobrovskii M. V. Comparative analysis of the effect of traditional farming systems (slash and burn clearing, fallow, three-field system) on the soil cover of Central Russia. Ecology and soils. Selected lectures of the X AllRussian school. Pushchino: Joint Institute of Science and Technology, Research Center of Biological Research of AS USSR, 2001, vol. 4, pp. 136-145.

16. Bobrovskii M. V. Forest soils of European Russia: biotic and anthropogenic formation factors. Moscow: KMK, 2010, 359 p.

17. Kyuster Kh. History of forests. A view from Germany: translation from German. Moscow: Higher school of economics, 2012, $304 \mathrm{p}$.

18. Kalyakin V. N. On the Causes and Consequences of the Destruction of Mammoth Faunas. Biology Bull. Reviews. 2014, vol. 4, no. 4, pp. 340-362.

19. Kalyakin V. N. On theriofauna transformation features in Palaearctic and Nearctic regions at the end of Cenozoic. Progress of modern biology. 2015, vol. 135, no. 4, pp. 414-433.

20. Vegetation of the European part of USSR. Leningrad: Science, 1980, $431 \mathrm{p}$.

21. Bobrinsky N. A., Zenkevich L. A., Birshtein Y. A. Geography of animals. Moscow: Sov. science, 1946,455 p.

22. Pavlinov I. Y. Nature of Russia: animal life. Mammals. Moscow: Ast, 1999, part 2, 624 p.

23. Golubeva Y. V. Climate and vegetation of the Holocene in the Komi republic's territory. Lithosphere. 2008, no. 2, pp. 124-132.

24. Smirnova O. V., Khanina L. G., Bobrovskii M. V., Turubanova S. A. Eastern European taiga: modern condition and genesis. Population, community, evolution. Kazan: New knowledge, 2002, part 2, pp. 211-227.

25. Zozulin, G. M. Forests of the lower Don. Rostov-on-Don: Publishing of Rostov university, 1992, 208 p.

26. Ponomarenko E. V. Methodological approaches to analyzing succession processes in a soil cover. Succession processes in Russian reserves and problems of biological diversity preservation. Edited by O. V. Smirnova, E. S. Shaposhnikov. Saint-Petersburg: PBO, 1999, pp. 34-57.

27. Krishtofovich A. N. Plant cover evolution in the geological past and main factors thereof. Materials on the history of flora and vegetation of USSR. Moscow; Leningrad: Publishing of AS USSR, 1947, pp. 21-86.

28. McKenna M. C., Bell S. K. Classification of Mammals Above the Species Level. New York: Columbia University Press, 1998, $631 \mathrm{p}$.

29. Alifanov V. R. Dinosauria superorder. Fossil reptiles and birds. Moscow: Geos, 2012, part 2, pp. $153-355$.

30. Puchkov P. V. Noncompensated extinctions in the Pleistocene: an estimated mechanism of the crisis. Preprint. Kiev: Institute of zoology of AS UkSSR, 1989, 60 p.

31. Puchkov P. V. Noncompensated Wurm extinctions. Message 2. Transformation of environment by giant phytophages. Bulletin of zoology. 1992, no. 1, pp. 58-66.

32. Levi K. G., Zadonina N. V., Yazaev S. A. Radio carbonic chronology of natural and social phenomena of the northern hemisphere. Irkutsk: Publishing of Irkutsk State University, 2009, vol. 1, 715 p.

33. Gromov V. I. Paleontological and archeological substantiation of stratigraphy of continental sedimentations of the Quaternary in the USSR territory. Proceedings of Institute of Geological sciences of AS USSR. Geological series. 1948, issue 64, no. 17, 521 p.

34. Pidoplichko I. G. On the ice age. Kiev: Publishing of AS UkSSR, 1951, issue 2, Biological and geographic features of European representatives of the Quaternary fauna, $264 \mathrm{p}$.

35. Pidoplichko I. G. On the ice age. Kiev: Publishing of AS UkSSR, 1954, issue 3, History of the Quaternary fauna of the European part of USSR, $220 \mathrm{p}$.

36. Lindberg G. U. The Quaternary in view of biogeographic data. Moscow: Publishing of AN USSR, 1955, 335 p.

37. Vasylyev V. B. Relicts and endemics of North-Western Europe. Materials on the history of flora and vegetation of USSR. Moscow; Leningrad: Publishing of AS USSR, 1964, issue 4, pp. 239-284.

38. Dorofeev P. I. New data on the Pleistocene floras of Belarus and Smolensk region. Materials on the history of flora and vegetation of USSR. Moscow; Leningrad: Publishing of AS USSR, 1963, issue 4, pp. 5-180.

39. Udra I. F. Dissemination of plants and issues of paleo- and biogeography. Kiev: Scientific idea, 1988,200 p.

40. Grichuk V. P. History of flora and vegetation of the Russian plain in the Pleistocene. Moscow: Science, $1989,180 \mathrm{p}$.

41. Kosintsev P. A., Borodin A. V. Theriofauna of the estern slope of the North Ural in the late Pleistocene and Holocene. Proceedings of Zoological Institute of RAS. 1990, vol. 212, pp. 120-134.

42. Vorobyev A. A. Pleistocene remains of bears (genus Ursus) in Western Siberia. Results and prospects of Siberian theriology development. Irkutsk, 2001, pp. 29-34.

43. Kalyakin V. N. An alternative to the hypothesis of giant glacier covers. Proceedings of Moscow center of RGS. Biogeography. Moscow, 2003, issue 11, pp. 62-73.

44. Danilov I. D. Marine subarctic plains in the Pleistocene. Moscow: MSU, 1978, 198 p.

45. Klige R. K., Voronov A. M., Selivanov A. O. Formation and long-term changes of the water regime of the East European plain. RAS. Institute of water problems. Moscow, 1993, 129 p.

46. Krivolutsky A. E. The relief and bowels of the Earth. Moscow: Idea, 1977, 300 p.

47. Tugarinov A. Y. On the origin of the Arctic fauna. Nature. 1929, no. 7-8, pp. 654-680. 
48. Velichko A. A. Natural complex in the Pleistocene: IX congress of INQUA: New Zealand. Moscow: Science, $1973,256 \mathrm{p}$.

49. Velichko A. A. Problems of paleogeography and chronology of the early and middle Pleistocene. Age and dissemination of the maximum glaciation of Eastern Europe. Moscow: Science, 1980, pp. 189-208.

50. Zubakov V. A. Global climatic events of the Pleistocene. Leningrad: Hydrometeo publishing, 1986, 288 p.

51. Groswald M. G., Groswald M. G. Cataclysmic megafloods in Eurasia and the polar ice sheets: Experience of geomorphological analysis of continental paleogydrological systems. RAS, Institute of Geography. Moscow: Scientific world, 1999, $117 \mathrm{p}$.

52. Udra I. F. Dissementation and migration of woody plants in the temperate zone of Eurasia: report of a doctor of biological sciences. Moscow, 1990, 39 p.

53. Chuvardinsky V. G. On the glacier theory. The origin of glacial formations. Appatites, 1998, 302 p.

54. Chuvardinsky V. G. Did continental glaciation take place? Myths and reality. Lambert Academic Publishing, 2014, 284 p.

55. Kuzin I. L. Geomorphological levels of the north-west of the Russian plain. Proceedings of RGS. 2004, vol. 136, issue 6, pp. 9-30.

56. Gromov I. M. Upper Quaternary rodents of the Samarskaya Luka and conditions of burials and accumulationof their remains. Proceedings of Zoological Institute of AS USSR. Moscow; Leningrad: AS USSR, 1957, vol. 22, pp. $112-150$.

57. Kuzmina I. E. Theriofauna formation in the North Urals in the late Anthropogene. Proceedings of Zoological Institute of AS USSR. 1971, vol. 49, pp. 44-122.

58. Potapova O. R. Bird remains in Pleistocene sedimentations in the Medvezhya cave in the North Urals. Proceedings of Zoological Institute of AS USSR. 1990, vol. 212, pp. 135-152. (202 changed to 212).

59. Latypova E. K., Yarheemovich B. L. Geochronology of the Pleistocene and Holocene in the Fore-Urals. Radiocarbon. 1993, vol. 35, no. 3, pp. 441-447.

60. Smirnov N. G., Teterina A. A. Dissemination and numbers of steppe species of small mammals in the North Urals in the late Pleistocene and Holocene. VI congress of Theriological society: report theses. Moscow, 1999, p. 238.

61. Bachura O. P. Large mammals of the eastern slope of the North Urals. Results and prospects of Siberian theriology development. Irkutsk, 2001, pp. 26-29.

62. Bachura O. P. The late Pleistocene theriofauna of the North Urals. Theriofauna of Russia and adjacent territories: proceedings of the International meeting. Moscow, 2003, p. 38.

63. Borodin A. V., Kosintsev P. A. Pleistocene mammals of the north of Western Siberia. The mammoth and its environment: 200 years of research. Moscow: Geos, 2001, pp. 244-252.

64. Kosintsev P. A. History of the large mammal fauna of tundra and taiga zones of Western Siberia. VI congress of Theriological society: report theses. Moscow, 1999, p. 126.

65. Kosintsev P. A. Formation of the modern theriofauna of Western Siberia. Results and prospects of Siberian theriology development. Irkutsk, 2001, pp. 111-116.

66. Kosintsev P. A. Extinction of mammals on the territory of Europe at the end of the Pleistocene - Holocene. Evolution of European ecosystem during the transition from the Pleistocene to the Holocene (24-8 thousand years ago). Moscow: KMK, 2008, pp. 259-270.

67. Kosintsev P. A., Vorobyov A. A. Biology of the large cave bear (Ursus spelaeus Ros. et Hein.) in the Urals. The mammoth and its environment: 200 years of research. Moscow: Geos, 2001, pp. 266-278.

68. Kosintsev P. A., Podoprigora I. N. Findings of the porcupine Hystrix vinogradovi and the Asiatic black bear Ursus thibetanus in the late Pleistoceneв in the North Urals. Theriofauna of Russian and adjacent territories (VII congress of Theriological society). Moscow: Scientific world, 2003, p. 175.

69. Kosintsev P. A., Vorobyov A. A., Orlova L. A. Absolute date on fossil bears (genus Ursus) of the Middle Urals. Theriofauna of Russian and adjacent territories: proceedings of the International meeting. Moscow, 2003, pp. 174-175.

70. Podoprigora I. N. Local faunas of large mammals of the late-Pleistocene theriocomplex of the Kama Fore-Ural territory. Results and prospects of Siberian theriology development. Irkutsk, 2001, pp. 34-38.

71. Podoprigora I. N. Theriofauna of large mammals of the Perm Fore-Urals in the Pleistocene. Theriofauna of Russian and adjacent territories: proceedings of the International meeting. Moscow, 2003, p. 268.

72. Smirnov N. G. Mamont i ego okruzhenie: 200 let izucheniya [Mammoth and Its Environment: 200 Years of Investigations]. Moscow: Geos, 2001, pp. 209-219.

73. Smirnov N. G. On approaches to researching historical dynamics of animal population of small mammals. New archeozoological research in Russia. Dedicated to $100^{\text {th }}$ jubilee of V.I. Tsalkin. Moscow: Languages of Slavic culture, 2003, pp. 57-80.

74. Petrov A. N. Ungulate mammal fauna of the Middle Urals in the Holocene. Theriofauna of Russian and adjacent territories: proceedings of the International meeting. Moscow, 2003, p. 260.

75. Smirnov N. G., Kosintsev P. A., Kuzmina E. A. and others Ecology of Quaternary mammals in the Urals. Ecology. 2014, no. 6, pp. 403-409.

76. Atlas of Arctic. Moscow: CDGC USSR, 1985, 213 p.

77. Kalyakin V. N. To save northern forests. Forest and men. Moscow: Forest industry, 1991, pp. 6-8.

78. Khantemirov R. M., Shiyatov S. G. Main stages of lignose development in Yamal in the Holocene. Ecology. 1999, no. 3, pp. 163-169. 
79. Khantemirov R. M., Surkov A. Y., Gorlanova L. A. Climate change and formation of age generations of larch on the polar forest fronties in Yamal. Ecology. 2008, no. 5, pp. 323-328.

80. Smirnova O. V., Aleynikov A. A., Smirnov N. S., Lugovaya D. L. Peony taiga. Nature. 2014, no. 2, pp. $54-63$.

81. Matishov G. G. On the nature of Pleistocene glaciation of the Barenst shelf. Reports of AS USSR. 1997, vol. 232, no. 1 , pp. 184-187.

82. Kozharinov A. V. Dynamics of the plant cover of Eastern Europe in the Pleistocene - Holocene: dissertation to apply for the degree of the doctor of biological sciences. Moscow, 1994, $453 \mathrm{p}$.

83. Morozova O. V., Kozharinov A. V. Influence of historical factors on distribution of species richness of the flora of Eastern Europe. Proceedings of RAS. Geographical series. 2001, no. 5, pp. 39-50.

84. Budyko M. I. On causes of extinction of some animals at the end of the Pleistocene. Proceedings of AS USSR. Geographical series. 1967, no. 2, pp. 28-36.

85. Owen-Smith N. Pleistocene extinctions: the pivotal role of megaherbivores. Paleobiology. 1987, vol. 13, pp. 351-162.

86. Owen-Smith N. Megafaunal extinctions: the conservation message from 11000 Years B.P. Conserv. Biology. 1989, vol. 3, no. 4, pp. 405-412.

87. Antipina E. E., Maslov S. P. Some problems of studying the history of relationships between human economic activity and natural biocenoses. Evolutionary and historical anthropoecology. Moscow: Science, 1994, pp. 111-120.

88. Beregovaya N. A. Paleolithic locations of USSR. Moscow; Leningrad: Publishing of AS USSR, 1960,210 p.

89. Beregovaya N. A. Paleolithic locations of USSR. Leningrad: Science, 1984, $171 \mathrm{p}$.

90. Garutt N. V., Boeskorov G. G. Woolly rhinoceros: on the genus history. The mammoth and its environment: 200 years of research. Moscow: Geos, 2001, pp. 157-167.

91. Stuart A. J., Kosintsev P. A., Higham T. F. G. and Lister A. M. Pleistocene to Holocene extinction dynamics in giant deer and woolly mammoth. Nature. 2004, vol. 431, pp. 684-689.

92. Klimanov V. A. Cuclicism and quasiperiodicity of climatic variations in the Holocene. Paleoclimates of the Pleistocene and Holocene. Moscow: Science, 1989, pp. 29-33.

93. Neishtadt M. I. History of forests and paleogeography of USSR in the Holocene. Moscow: Societ science, 1957, $404 \mathrm{p}$.

94. Khotinsky N. A. The Holocene of Northern Eurasia. Moscow: Science, 1977, 198 p.

95. Vereshchagin N. K., Gromov I. M. Theriofauna formation in USSR in the Quaternary. Progress of modern theriology. Moscow: Science, 1977, pp. 32-45.

96. Vasylchuk Y. K., Petrova E. A., Serova A. K. Some features of paleogeography of the Holocene in Yamal. Bulletin of the commission for research of the Quaternary. Moscow: Science, 1983, no. 52, pp. 73-89.

97. Vartanyan S. L., Arslanov Kh. A., Tertychnaya T. V., Chernov S. B. Radiocarbon dating evidence for mammoths on Wrangyel Island, Arctic Ocean until 2000 BC. Radiocarbon. 1995, vol. 37, no. 1, pp. 1-7.

98. Gurina N. N. Ancient history of the North-West of the European part of USSR. Materials and studies on archeology (MSA). Moscow; Leningrad: Publishing of AS USSR, 1961, no. 87, 588 p.

99. Tsalkin B. I. Materials for the history of cattle-breeding and hunting in Ancient Rus. Materials and studies on archeology (MSA). Moscow; Leningrad: Publishing of AS USSR, 1956, no. 51, 185 p.

100. Tsalkin V. I. Ancient cattle-breeding of tribes of Eastern Europe and Middle Asia. Materials and studies on archeology (MSA). Moscow; Leningrad: Publishing of AS USSR, 1966, no. 135, 159 p.

101. Paaver K. L. Theriofauna formation and mammal changeability in Baltic region in the Holocene. Tartu, $1965,497 \mathrm{p}$.

102. Maslov S. P., Antipina E. E. On the issue of the role of hunting in economic life of Ancient Rus' population. Ecological aspects of paleoanthropological and archeological reconstructions. Moscow: IA RAS, 1992, pp. 179-190.

103. Alekseeva L. I., Kalyakin V. N., Krenke N. A. Archeozoological collection of the Dyakovo settlement excavations in Moscow. Archeological monuments of Moscow and Moscow region: proceedings of Historical Museum of Moscow. Moscow, 1996, pp. 24-44.

104. Zhegallo V. I., Kalandadze N. N., Kuznetsova T. V., Rautian A. S. Fate of Holarctic megafauna in the late Anthropogene. The mammoth and its environment: 200 years of research. Moscow: Geos, 2001, pp. 287-306.

105. Kalyakin V. N. Fauna and natural conditions of a settlement. Historical monuments of II expedition to Kamchatka. Moscow: Scientific world, 2002, pp. 184-193.

106. Kuznetsova T. V., Noskova N. G., Kalyakin V. N., Esin D. N. Results of examination of archeological materials and excavations of Rostislav settlement (1998-2001). Archeology of Moscow region: proceedings of the scientific seminar. Moscow, 2004, pp. 34-41.

107. Vereshchagin N. K. Mammals of the Caucasus. History of fauna formation. Moscow: Publishing of AS USSR, $1959,703 \mathrm{p}$.

108. Catalogue of mammals of USSR. Leningrad: Science, 1981, $456 \mathrm{p}$.

109. Matthes H. W. Dissemination of mammals in ancient times. Handbook of zoology. Berlin, 1962, pp. 1-198.

110. Ukkonen P., Pekka J., Jangner H., Donner J. New radiocarbon dates from Finnish mammoths indicating large ice-free areas in Fennoscandia during the Middle Weichselian. J. Quaternary Science. 1999, vol. 14, no. 7, pp. 711-714.

111. Shumkin V. Y. The Mesolithic of the Kola Peninsula. Soviet archeology. 1988, no. 2, pp. 15-33.

112. Shnirelman V. A. Late-primitive community of crop-growers - cattle-breeders and higher hunters, fishermen and gatherers. History of primitive society. The age of primitive tribal community. Moscow: Science, 1986, pp. $236-426$.

113. Tyuryukanov A. N. What do soils tell us and what are they silent about. Moscow: VO Agropromizdat, $1990,224 \mathrm{p}$.

114. Krupenina L. A. Signs of anthropogenic impact on the plant cover of the central part of the Central Russian Upland in the Holocene. Palynology of the Holocene and marine science. Moscow, 1973, pp. 91-97. 
115. Serebryannaya T. A. On the Holocene history of forests of the Central Russian Upland. Bulletin of the commission for research of the Quaternary. 1980, no. 50, pp. 178-185.

116. Serebryannaya T. A. Human impact on vegetation of the Central Russian Upland (by palynological data). Anthropogenic factors in the history of development of modern ecosystems. Moscow: Science, 1981, pp. 52-60.

117. Khotinsky N. A. Holocene chronosections: paleogeographical discussion problems of the Holocene. Nature development in USSR territory in the late Pleistocene and Holocene. Moscow: Science, 1982, pp. 142-147.

118. Khotinsky N. A. Discussion problems of reconstruction and correlation of Holocene paleoclimates. Paleoclimates of the Pleistocene and Holocene. Moscow: Science, 1989, pp. 12-17.

119. Gmelin S. G. Journey through Russia to research three kingdoms of nature. Saint-Petersburgb, 1771, part I, Journey from Saint-Petersburg to Cherkassk - the capital of Don Cossacks - in 1768 and 1769, 272 p.

120. Grosset G. Forest and steppe in their relationship within the forest-steppe zone of Europe. Voronezh: Oblplan TsChO, 1930, II, $94 \mathrm{p}$.

121. Zuev V. Materials on Siberian ethnography in XVIII century (1771-1772). Description of gentile peoples, Ostyaks and Samoyeds residing Berezovsky district of Siberian province, written by a student - Vasily Zuev. Moscow: Publishing of AS USSR, 1947, $126 \mathrm{p}$.

122. Pallas P. S. A journey around the Russian State. Saint-Petersburg, 1773, part 1, 117 p.

123. Seitbutis A. A. Important features of development of the Holocene history in the Baltic region. Nature development in USSR territory in the late Pleistocene and Holocene. Moscow: Science, 1982, pp. 162-168.

124. Gorodkov B. N. Materials for examination of Quaternary landscapes of Arctic. Botanical journal. 1954, vol. 39, no. 1, pp. 16-29.

125. Kalyakin V. N. Mammals in ecosystems of the south of Yamal. Mammals in ground ecosystems. Moscow: Science, 1985, pp. 67-99.

126. Kalyakin V. N. On dissemination of some mammals, amphibians and reptiles in the far North-East of Europe and in the south of Yamal. Bulletin of MSN. Biological department. 2002, vol. 107, issue 2, pp. 23-30.

127. Kuzmina I. E. Hourses of Northern Eurasia from the Pliocene to modern times. Proceedings of Zoological Institute of RAS. 1997, vol. 273, 223 p.

128. Alkseeva L. I. Subfossil horses of Moscow district. Bulletin of CRQ. 2001, no. 64, pp. 32-34.

129. Geptner V. G., Nasimovich A. A., Bannikov A. G. Mammals of the Soviet Union. Moscow: Higher school, 1961, vol. 1, Artiodactyles and perissodactyles, $776 \mathrm{p}$.

130. Boeskorov G. G. The red deer in the Pleistocene in North-Eastern Asia and Alaska. Theriofaune of Russia and adjacent territories: proceedings of the International meeting, 6 February 2003. Moscow, 2003, pp. 55-56.

131. Smirnova O. V. The role of key species in preserving forest biodiversity. Russian Conservation News. 1998 , no. 15, Spring, pp. 17-18.

132. Bartalev S. A., Ershov D. V., Isaev A. S., Potapov P. V., Turubanova S. A., Yaroshenko A. Y. Forest map of the Russian Federation, colored by prevailing groups of tree species and canopy density (scale 1: 14000 000). Moscow, 2004, 1 p.

133. Rysin L. P., Savelyeva L. I. Spruce forests of Russia. Moscow: Science, 2002, 335 p.

134. The red book of the Russian Federation. Animals. Moscow: Ast, 2001, 392 p.

135. Popov M. G. On the issue of the taiga origin. Collected papers on results of examination in the field of forestry and forest industry in the taiga zone of USSR. Moscow; Leningrad: Publishing of AS USSR, 1957, pp. 19-28.

136. Baranov V. I. Stages of flora and vegetation development in USSR in the Tertiary period. Kazan: Publishing of KSU, 1954, $362 \mathrm{p}$.

137. Vasylyev V. N. Origin of flora and vegetation of the Far East and Eastern Siberia. Materials on the history of flora and vegetation of USSR. Moscow; Leningrad: Publishing of AS USSR, 1958, issue 3, pp. 361-457.

138. Udra I. F. Interpretation of the paleogeographic situation of Polesye and adjacent regions on the basis of botanical data. Botanical journal. 1982, vol. 67, no. 1, pp. 94-100.

139. Evstigneev O. I. Population strategies of tree species. Eastern European forests: the history in the Holocene and modern times. Moscow: Science, 2004, bk. 1, pp. 176-204.

140. Pachosky I. K. Main features of flora development in South-Western Russia. Proceedings of Novorossiysk society of naturalists. Kherson, 1910, issue 34, $430 \mathrm{p}$.

141. Lavrenko E. M. History of flora and vegetation of USSR by data on modern dissemination of plants. Vegetation of USSR. Moscow; Leningrad: Publishing of AS USSR, 1938, vol. 1, pp. 235-296.

142. Shtegman B. K. On the origin of taiga avifauna. DAS USSR. 1931, Series A, no. 13, pp. 350-357.

143. Lugovaya D. L., Smirnova O. V., Zaprudina M. V., Aleynikov A. A., Smirnov V. E. Micromosaic organization and phytomass of soil cover in main types of dark coniferous forests of the Pechora-Ilych reserve. Ecology. 2011, no. 1 , pp. 3-10.

\section{Cnucoк лumepamypы}

1. Leskov, A. I. Principles of the natural system of plant associations / A. I. Leskov // Botanical journal of USSR. 1943. - № 2. -pp. 37-46.

2. Sochava, V. B. Problems of florogenesis and philocoenogenesis of the Manchurian mixed forest / V. B. Sochava // Materials on the history of flora and vegetation of USSR. - M. ; L. : Publishing of AS USSR, 1946. - Issue. 2. pp. 283-320. 
3. Tolmachev, A. I. On the history of origin and development of the dark coniferous taiga / A. I. Tolmachev. - M. ; L. : Publishing of AS USSR, 1954. - $155 \mathrm{p}$.

4. Anti, T. Vegetation zones and their section in northwestern Europe / T. Anti, L. Hämet-Anti, J. Jalas // Ann. Bot. Fenn. - 1968. - Vol. 5. - P. 69-211.

5. Yurtsev, B. A. Problems of the dark coniferous taiga origin in view of new paleobotanic research / B. A. Yurtsev // Botanical journal. - 1972. - Vol. 57, № 11. - pp. 1455-1469.

6. Prilepsky, N. G. Problem of the taiga origin. On the history of the problem / N. G. Prilepsky // Botanical journal. 1993. - Vol. 78, № 8. - pp. 1-16.

7. Smirnova, O. V. Population organization of biocenotic cover of forest landscapes / O. V. Smirnova // Progress of modern biology. - 1998. - № 2. - pp. 25-39.

8. Modern zoning of Eastern Europe as a result of transformation of the late-pleistocene complex of key species / O. V. Smirnova, V. N. Kalyakin, S. A. Turubanova, M. V. Bobrovskii // The mammoth and its environment: 200 years of research. - M. : Geos, 2001. - pp. 200-208.

9. Genesis of the Eastern European taiga in the Holocene / O.V. Smirnova, V. N. Kalyakin, S. A. Turubanova, E. Y. Bakun // Regularities of secular dynamics of biogeocenoses. XXI reading in the memory of academician V. N. Sukachev. - M. : KMK, 2006. - pp. 18-65.

10. Eastern European forests: history in the Holocene and modern times / edited by O. V. Smirnova. - M. : Science, 2004. - Book 1. - 479 p. ; book 2. -575 p.

11. The ecological history of European forest. 1998. / ed. by K. Kirby, C. Watkins. - Cambridge : Cambridge University Press. -384 p.

12. Eastern European broad-leaved forests / edited by O. V. Smirnova. - M. : Science, 1994. - 364 p.

13. Vera, F. W. M. Grazing ecology and forest history / F. W. M. Vera. - Oxon ; New York : CABI Publishing, 2000. $506 \mathrm{p}$.

14. Vera, F. W. M. Large herbivores: missing partners of western European light-demanding tree and shrub species? / F. W. M. Vera, E. Bakker, H. Olff // Large herbivore ecology, ecosystem dynamics and conservation. Biology series / ed. by K. Danell, P. Duncan, R. Bergstrom, J. Pastor.- Cambridge : Cambridge University Press, 2006. P. 203-231.

15. Bobrovskii, M. V. Comparative analysis of the effect of traditional farming systems (slash and burn clearing, fallow, three-field system) on the soil cover of Central Russia / M. V. Bobrovskii // Ecology and soils. Selected lectures of the X All-Russian school. - Pushchino : Joint Institute of Science and Technology, Research Center of Biological Research of AS USSR, 2001. - Vol. 4. - pp. 136-145.

16. Bobrovskii, M.V. Forest soils of European Russia: biotic and anthropogenic formation factors / M. V. Bobrovskii. M. : KMK, 2010. - 359 p.

17. Kyuster, Kh. History of forests. A view from Germany : translation from German / Kh. Kyuster. - M. : Higher school of economics, 2012. - 304 p.

18. Kalyakin, V. N. On the Causes and Consequences of the Destruction of Mammoth Faunas / V. N. Kalyakin // Biology Bull. Reviews. - 2014. - Vol. 4, № 4. - P. 340-362.

19. Kalyakin, V. N. On theriofauna transformation features in Palaearctic and Nearctic regions at the end of Cenozoic / V. N. Kalyakin // Progress of modern biology. - 2015. - Vol. 135, № 4. - pp. 414-433.

20. Vegetation of the European part of USSR. - L. : Science, 1980. - 431 p.

21. Bobrinsky, N. A. Geography of animals / N. A. Bobrinsky, L. A. Zenkevich, Y. A. Birshtein. - M. : Sov. science, 1946. $-455 \mathrm{p}$.

22. Pavlinov, I. Y. Nature of Russia: animal life. Mammals / I. Y. Pavlinov. - M. : Ast, 1999. - Part 2. - 624 p.

23. Golubeva, Y. V. Climate and vegetation of the Holocene in the Komi republic's territory / Y. V. Golubeva // Lithosphere. - 2008. - № 2. - pp. 124-132.

24. Eastern European taiga: modern condition and genesis / O. V. Smirnova, L. G. Khanina, M. V. Bobrovskii, S. A. Turubanova // Population, community, evolution. - Kazan : New knowledge, 2002. - Part 2. - pp. $211-227$.

25. Zozulin, G. M. Forests of the lower Don / G. M. Zozulin. - Rostov on Don : Publishing of Rostov university, 1992. -208 p.

26. Ponomarenko, E. V. Methodological approaches to analyzing succession processes in a soil cover / E. V. Ponomarenko // Succession processes in Russian reserves and problems of biological diversity preservation / edited by O. V. Smirnova, E. S. Shaposhnikov. - SPb. : PBO, 1999. - pp. 34-57.

27. Krishtofovich, A. N. Plant cover evolution in the geological past and main factors thereof / A. N. Krishtofovich // Materials on the history of flora and vegetation of USSR. - M. ; L. : Publishing of AS USSR, 1947. - pp. 21-86.

28. McKenna, M. C. Classification of Mammals Above the Species Level / M. C. McKenna, S. K. Bell. - New York : Columbia University Press, 1998. - 631 p.

29. Alifanov, V. R. Dinosauria superorder/ V. R. Alifanov // Fossil reptiles and birds. - M. : Geos, 2012. - Part 2. pp. 153-355.

30. Puchkov, P. V. Noncompensated extinctions in the Pleistocene: an estimated mechanism of the crisis / P. V. Puchkov. - Preprint. - Kiev : Institute of zoology of AS UkSSR, 1989. - 60 p.

31. Puchkov, P. V. Noncompensated Wurm extinctions. Message 2. Transformation of environment by giant phytophages / P. V. Puchkov // Bulletin of zoology. - 1992. - № 1. - pp. 58-66. 
32. Levi, K. G. Radio carbonic chronology of natural and social phenomena of the northern hemisphere / K. G. Levi, N. V. Zadonina, S. A. Yazaev. - Irkutsk : Publishing of Irkutsk State University, 2009. - Vol.1. - 715 p.

33. Gromov, V. I. Paleontological and archeological substantiation of stratigraphy of continental sedimentations of the Quaternary in the USSR territory / V. I. Gromov // Proceedings of Institute of Geological sciences of AS USSR. Geological series. - 1948. - Issue. 64, № 17. - 521 p.

34. Pidoplichko, I. G. On the ice age / I. G. Pidoplichko. - Kiev : Publishing of AS UkSSR, 1951. - Issue. 2. Biological and geographic features of European representatives of the Quaternary fauna. - $264 \mathrm{p}$.

35. Pidoplichko, I. G. On the ice age / I. G. Pidoplichko. - Kiev : Publishing of AS UkSSR, 1954. - Issue. 3. History of the Quaternary fauna of the European part of USSR. - 220 p.

36. Lindberg, G. U. The Quaternary in view of biogeographic data / G. U. Lindberg. - M. : Publishing of AN USSR, 1955. $-335 \mathrm{p}$.

37. Vasylyev, V. B. Relicts and endemics of North-Western Europe / V. B. Vasylyev // Materials on the history of flora and vegetation of USSR. - M. ; L. : Publishing of AS USSR, 1964. - Issue 4. - pp. 239-284.

38. Dorofeev, P. I. New data on the Pleistocene floras of Belarus and Smolensk region / P. I. Dorofeev // Materials on the history of flora and vegetation of USSR. - M. ; L. : Publishing of AS USSR, 1963. - Issue. 4. - pp. 5-180.

39. Udra, I. F. Dissemination of plants and issues of paleo- and biogeography / I. F. Udra. - Kiev : Scientific idea, 1988. $-200 \mathrm{p}$.

40. Grichuk, V. P. History of flora and vegetation of the Russian plain in the Pleistocene / V. P. Grichuk. - M. : Science, 1989. - $180 \mathrm{p}$.

41. Kosintsev, P. A. Theriofauna of the estern slope of the North Ural in the late Pleistocene and Holocene / P. A. Kosintsev, A. V. Borodin // Proceedings of Zoological Institute of RAS. - 1990. - Vol. 212. - pp. $120-134$.

42. Vorobyev, A. A. Pleistocene remains of bears (genus Ursus) in Western Siberia / A. A. Vorobyev // Results and prospects of Siberian theriology development. - Irkutsk, 2001. - pp. 29-34.

43. Kalyakin, V. N. An alternative to the hypothesis of giant glacier covers / V. N. Kalyakin // Proceedings of Moscow center of RGS. Biogeography. - M., 2003. - Issue. 11. - pp. 62-73.

44. Danilov, I. D. Marine subarctic plains in the Pleistocene / I. D. Danilov. - M. : MSU, 1978. - 198 p.

45. Klige, R. K. Formation and long-term changes of the water regime of the East European plain / R. K. Klige ; A. M. Voronov, A. O. Selivanov ; RAS. Institute of water problems. - M., 1993. - 129 c.

46. Krivolutsky, A. E. The relief and bowels of the Earth / A. E. Krivolutsky. - M. : Idea, 1977. - 300 p.

47. Tugarinov, A. Y. On the origin of the Arctic fauna / A. Y. Tugarinov // Nature. - 1929. - № 7-8. - pp. 654-680.

48. Velichko, A. A. Natural complex in the Pleistocene: IX congress of INQUA: New Zealand / A. A. Velichko. - M. : Science, 1973. $-256 \mathrm{p}$.

49. Velichko, A. A. Problems of paleogeography and chronology of the early and middle Pleistocene // Age and dissemination of the maximum glaciation of Eastern Europe / A. A. Velichko. - M. : Science, 1980. - pp. 189-208.

50. Zubakov, V. A. Global climatic events of the Pleistocene / V. A. Zubakov. - L. : Hydrometeo publishing, 1986. $288 \mathrm{p}$.

51. Groswald, M. G. Cataclysmic megafloods in Eurasia and the polar ice sheets: Experience of geomorphological analysis of continental paleogydrological systems / M. G. Groswald ; RAS, Institute of Geography. - M. : Scientific world, 1999. - $117 \mathrm{p}$.

52. Udra, I. F. Dissementation and migration of woody plants in the temperate zone of Eurasia : report of a doctor of biological sciences / Udra I. F. - M., 1990. - 39 p.

53. Chuvardinsky, V. G. On the glacier theory. The origin of glacial formations / V. G. Chuvardinsky. - Appatites, 1998. - $302 \mathrm{p}$.

54. Chuvardinsky, V. G. Did continental glaciation take place? Myths and reality / V. G. Chuvardinsky. - Lambert Academic Publishing, 2014. - 284 p.

55. Kuzin, I. L. Geomorphological levels of the north-west of the Russian plain / I. L. Kuzin // Proceedings of RGS. 2004. - Vol. 136, issue. 6. - pp. 9-30.

56. Gromov, I. M. Upper Quaternary rodents of the Samarskaya Luka and conditions of burials and accumulationof their remains / I. M. Gromov // Proceedings of Zoological Institute of AS USSR. - M. ; L.: AS USSR, 1957. Vol. 22. - pp. 112-150.

57. Kuzmina, I. E. Theriofauna formation in the North Urals in the late Anthropogene / I. Е. Кузьмина // Proceedings of Zoological Institute of AS USSR. - 1971. - Vol. 49. - pp. 44-122.

58. Potapova, O. R. Bird remains in Pleistocene sedimentations in the Medvezhya cave in the North Urals / O. R. Potapova // Proceedings of Zoological Institute of AS USSR. - 1990. - Vol. 212. - pp. $135-152$. (202 changed to 212).

59. Latypova, E. K. Geochronology of the Pleistocene and Holocene in the Fore-Urals / E. K. Latypova, B. L. Yarheemovich // Radiocarbon. - 1993. - Vol. 35. - № 3. - P. 441-447.

60. Smirnov, N. G. Dissemination and numbers of steppe species of small mammals in the North Urals in the late Pleistocene and Holocene / N. G. Smirnov, A. A. Teterina // VI congress of Theriological society : report theses M., 1999. - p. 238.

61. Bachura, O. P. Large mammals of the eastern slope of the North Urals / O. P. Bachura // Results and prospects of Siberian theriology development. - Irkutsk, 2001. - pp. 26-29. 
62. Bachura, O. P. The late Pleistocene theriofauna of the North Urals / O. P. Bachura // Theriofauna of Russia and adjacent territories: proceedings of the International meeting. - M., 2003. - p. 38.

63. Borodin, A. V. Pleistocene mammals of the north of Western Siberia / A. V. Borodin, P. A. Kosintsev // The mammoth and its environment: 200 years of research. - M. : Geos, 2001. - pp. 244-252.

64. Kosintsev, P. A. History of the large mammal fauna of tundra and taiga zones of Western Siberia / P. A. Kosintsev // VI congress of Theriological society : report theses. - M., 1999. - p. 126.

65. Kosintsev P. A. Formation of the modern theriofauna of Western Siberia / P. A. Kosintsev // Results and prospects of Siberian theriology development. - Irkutsk, 2001. - pp. 111-116.

66. Kosintsev, P. A. Extinction of mammals on the territory of Europe at the end of the Pleistocene - Holocene / P. A. Kosintsev // Evolution of European ecosystem during the transition from the Pleistocene to the Holocene (24-8 thousand years ago). - M. : KMK, 2008. - pp. 259-270.

67. Kosintsev, P. A. Biology of the large cave bear (Ursus spelaeus Ros. et Hein.) in the Urals / P. A. Kosintsev, A. A. Vorobyov // The mammoth and its environment: 200 years of research. - M. : Geos, 2001. - pp. 266-278.

68. Kosintsev, P. A. Findings of the porcupine Hystrix vinogradovi and the Asiatic black bear Ursus thibetanus in the late Pleistoceneв in the North Urals / P. A. Kosintsev, I. N. Podoprigora // Theriofauna of Russian and adjacent territories (VII congress of Theriological society). - M. : Scientific world, 2003. - p. 175.

69. Kosintsev, P. A. Absolute date on fossil bears (genus Ursus) of the Middle Urals / P. A. Kosintsev, A. A. Vorobyov, L. A. Orlova // Theriofauna of Russian and adjacent territories: proceedings of the International meeting. M., 2003. - pp. 174-175.

70. Podoprigora, I. N. Local faunas of large mammals of the late-Pleistocene theriocomplex of the Kama Fore-Ural territory / I. N. Podoprigora // Results and prospects of Siberian theriology development. - Irkutsk, 2001. - pp. 34-38.

71. Podoprigora, I. N. Theriofauna of large mammals of the Perm Fore-Urals in the Pleistocene / I. N. Podoprigora // Theriofauna of Russian and adjacent territories: proceedings of the International meeting. - M., 2003. - p. 268.

72. Смирнов, Н. Г. Зональное распределение млекопитающих в позднем валдае на Урале / Н. Г. Смирнов // Мамонт и его окружение: 200 лет изучения. - М. : Геос, 2001. - С. 209-219.

73. Smirnov, N. G. On approaches to researching historical dynamics of animal population of small mammals / N. G. Smirnov // New archeozoological research in Russia. Dedicated to $100^{\text {th }}$ jubilee of V.I. Tsalkin. - M. : Languages of Slavic culture, 2003. - pp. 57-80.

74. Petrov, A. N. Ungulate mammal fauna of the Middle Urals in the Holocene / A. N. Petrov // Theriofauna of Russian and adjacent territories: proceedings of the International meeting. - M., 2003. - p. 260.

75. Smirnov, N. G. Ecology of Quaternary mammals in the Urals / N. G. Smirnov, P. A. Kosintsev, E. A. Kuzmina [and others] // Ecology. - 2014. - № 6. - pp. 403-409.

76. Atlas of Arctic. - M. : CDGC USSR, 1985. - 213 p.

77. Kalyakin, V. N. To save northern forests / V. N. Kalyakin // Forest and men. - M. : Forest industry, 1991. - pp. 6-8.

78. Khantemirov, R. M. Main stages of lignose development in Yamal in the Holocene / R. M. Khantemirov, S. G. Shiyatov // Ecology. - 1999. - № 3. - pp. 163-169.

79. Khantemirov, R. M. Climate change and formation of age generations of larch on the polar forest fronties in Yamal / R. M. Khantemirov, A. Y. Surkov, L. A. Gorlanova // Ecology. - 2008. - № 5. - pp. 323-328.

80. Peony taiga / O. V. Smirnova, A. A. Aleynikov, N. S. Smirnov, D. L. Lugovaya // Nature. - 2014. - № 2. pp. 54-63.

81. Matishov, G. G. On the nature of Pleistocene glaciation of the Barenst shelf / G. G. Matishov // Reports of AS USSR. - 1997. - Vol. 232, № 1. - pp. 184-187.

82. Kozharinov, A. V. Dynamics of the plant cover of Eastern Europe in the Pleistocene - Holocene : dissertation to apply for the degree of the doctor of biological sciences / Kozharinov A. V. - M., 1994. - 453 p.

83. Morozova, O. V. Influence of historical factors on distribution of species richness of the flora of Eastern Europe / O. V. Morozova, A. V. Kozharinov // Proceedings of RAS. Geographical series. - 2001 . - № 5. - pp. 39-50.

84. Budyko, M. I. On causes of extinction of some animals at the end of the Pleistocene / M. I. Budyko // Proceedings of AS USSR. Geographical series. - 1967. - № 2. - pp. 28-36.

85. Owen-Smith, N. Pleistocene extinctions: the pivotal role of megaherbivores / N. Owen-Smith // Paleobiology. 1987. - Vol. 13. - P. 351-162.

86. Owen-Smith, N. Megafaunal extinctions: the conservation message from 11000 Years B.P. / N. Owen-Smith // Conserv. Biology. - 1989. - Vol. 3, № 4. - P. 405-412.

87. Antipina, E. E. Some problems of studying the history of relationships between human economic activity and natural biocenoses / E. E. Antipina, S. P. Maslov // Evolutionary and historical anthropoecology. - M. : Science, 1994. - pp. 111-120.

88. Beregovaya, N. A. Paleolithic locations of USSR / N. A. Beregovaya. - M. ; L. : Publishing of AS USSR, 1960. $210 \mathrm{p}$.

89. Beregovaya, N. A. Paleolithic locations of USSR / N. A. Beregovaya. - L. : Science, 1984. - 171 p.

90. Garutt, N. V. Woolly rhinoceros: on the genus history / N. V. Garutt, G. G. Boeskorov // The mammoth and its environment: 200 years of research. - M. : Geos, 2001. - pp. 157-167.

91. Pleistocene to Holocene extinction dynamics in giant deer and woolly mammoth / A. J. Stuart, P. A. Kosintsev, T. F. G. Higham, and A. M. Lister // Nature. - 2004. - Vol. 431. - P. 684-689. 
92. Klimanov, V. A. Cuclicism and quasiperiodicity of climatic variations in the Holocene / V. A. Klimanov // Paleoclimates of the Pleistocene and Holocene. - M. : Science, 1989. - pp. 29-33.

93. Neishtadt, M. I. History of forests and paleogeography of USSR in the Holocene / M. I. Neishtadt. - M. : Societ science, 1957. $-404 \mathrm{p}$.

94. Khotinsky, N. A. The Holocene of Northern Eurasia / N. A. Khotinsky. - M. : Science, 1977. - 198 p.

95. Vereshchagin, N. K. Theriofauna formation in USSR in the Quaternary / N. K. Vereshchagin, I. M. Gromov // Progress of modern theriology. - M. : Science, 1977. - pp. 32-45.

96. Vasylchuk, Y. K. Some features of paleogeography of the Holocene in Yamal / Y. K. Vasylchuk, E. A. Petrova, A. K. Serova // Bulletin of the commission for research of the Quaternary. - M. : Science, 1983. - № 52. - pp. 73-89.

97. Radiocarbon dating evidence for mammoths on Wrangyel Island, Arctic Ocean until 2000 BC / S. L. Vartanyan, Kh. A. Arslanov, T. V. Tertychnaya, S. B. Chernov // Radiocarbon. - 1995. - Vol. 37. - № 1. - P. 1-7.

98. Gurina, N. N. Ancient history of the North-West of the European part of USSR / N. N. Gurina // Materials and studies on archeology (MSA). - M. ; L. : Publishing of AS USSR, 1961. - № 87. - 588 p.

99. Tsalkin, B. I. Materials for the history of cattle-breeding and hunting in Ancient Rus / V. I. Tsalkin // Materials and studies on archeology (MSA). - M. ; L. : Publishing of AS USSR, 1956. - № 51. - 185 p.

100. Tsalkin, V. I. Ancient cattle-breeding of tribes of Eastern Europe and Middle Asia // Materials and studies on archeology (MSA). - M. ; L. : Publishing of AS USSR, 1966. - № 135. - 159 p.

101. Paaver, K. L. Theriofauna formation and mammal changeability in Baltic region in the Holocene / K. L. Paaver. Tartu, 1965. - $497 \mathrm{p}$.

102. Maslov, S. P. On the issue of the role of hunting in economic life of Ancient Rus' population / S. P. Maslov, E. E. Antipina // Ecological aspects of paleoanthropological and archeological reconstructions. - M. : IA RAS, 1992. pp. 179-190.

103. Alekseeva, L. I. Archeozoological collection of the Dyakovo settlement excavations in Moscow / L. I. Alekseeva, V. N. Kalyakin, N. A. Krenke // Archeological monuments of Moscow and Moscow region: proceedings of Historical Museum of Moscow. - M., 1996. - pp. 24-44.

104. Fate of Holarctic megafauna in the late Anthropogene / V. I. Zhegallo, N. N. Kalandadze, T. V. Kuznetsova, A. S. Rautian // The mammoth and its environment: 200 years of research. - M. : Geos, 2001. - pp. 287-306.

105. Kalyakin, V. N. Fauna and natural conditions of a settlement / V. N. Kalyakin // Historical monuments of II expedition to Kamchatka. - M. : Scientific world, 2002. - pp. 184-193.

106. Results of examination of archeological materials and excavations of Rostislav settlement (1998-2001) / T. V. Kuznetsova, N. G. Noskova, V. N. Kalyakin, D. N. Esin // Archeology of Moscow region : proceedings of the scientific seminar. - M., 2004. - pp. 34-41.

107. Vereshchagin, N. K. Mammals of the Caucasus. History of fauna formation / N. K. Vereshchagin. - M. : Publishing of AS USSR, 1959. - 703 p.

108. Catalogue of mammals of USSR. - L. : Science, 1981. - $456 \mathrm{p}$.

109. Matthes, H. W. Dissemination of mammals in ancient times / H. W. Matthes // Handbook of zoology. - Berlin, 1962. - P. 1-198.

110. New radiocarbon dates from Finnish mammoths indicating large ice-free areas in Fennoscandia during the Middle Weichselian / P. Ukkonen, J. Pekka, H. Jangner, J. Donner // J. Quaternary Science. - 1999. - Vol. 14, № 7. P. 711-714.

111. Shumkin, V. Y. The Mesolithic of the Kola Peninsula / V. Y. Shumkin // Soviet archeology. - 1988. - № 2. pp. 15-33.

112. Shnirelman, V. A. Late-primitive community of crop-growers - cattle-breeders and higher hunters, fishermen and gatherers / V. A. Shnirelman // History of primitive society. The age of primitive tribal community. - M. : Science, 1986. - pp. 236-426.

113. Tyuryukanov, A. N. What do soils tell us and what are they silent about / A. N. Tyryukanov. - M. : VO Agropromizdat, 1990. - 224 p.

114. Krupenina, L. A. Signs of anthropogenic impact on the plant cover of the central part of the Central Russian Upland in the Holocene / L. A. Krupenina // Palynology of the Holocene and marine science. - M., 1973. - pp. 91-97.

115. Serebryannaya, T. A. On the Holocene history of forests of the Central Russian Upland / T. A. Serebryanaya // Bulletin of the commission for research of the Quaternary. - 1980. - № 50. - pp. 178-185.

116. Serebryannaya, T. A. Human impact on vegetation of the Central Russian Upland (by palynological data) / T. A. Serebryannaya // Anthropogenic factors in the history of development of modern ecosystems. - M. : Science, 1981. - pp. 52-60.

117. Khotinsky, N. A. Holocene chronosections: paleogeographical discussion problems of the Holocene / N. A. Khotinsky // Nature development in USSR territory in the late Pleistocene and Holocene. - M. : Science, 1982. - pp. 142-147.

118. Khotinsky, N. A. Discussion problems of reconstruction and correlation of Holocene paleoclimates / N. A. Khotinsky // Paleoclimates of the Pleistocene and Holocene. - M. : Science, 1989. - pp. 12-17.

119. Gmelin, S. G. Journey through Russia to research three kingdoms of nature / S. G. Gmelin. - SPb., 1771. - Part I. Journey from Saint-Petersburg to Cherkassk - the capital of Don Cossacks - in 1768 and 1769. - 272 p.

120. Grosset, G. Forest and steppe in their relationship within the forest-steppe zone of Europe / G. Grosset. - Voronezh : Oblplan TsChO, 1930. - II. - 94 p. 
121. Zuev, V. Materials on Siberian ethnography in XVIII century (1771-1772). Description of gentile peoples, Ostyaks and Samoyeds residing Berezovsky district of Siberian province, written by a student - Vasily Zuev / V. Zuev. M. : Publishing of AS USSR, 1947. - $126 \mathrm{p}$.

122. Pallas, P. S. A journey around the Russian State / P. S. Pallas. - SPb., 1773. - Part 1. - 117 p.

123. Seitbutis, A. A. Important features of development of the Holocene history in the Baltic region / A. A. Seitbutis // Nature development in USSR territory in the late Pleistocene and Holocene. - M. : Science, 1982. - pp. $162-168$.

124. Gorodkov, B. N. Materials for examination of Quaternary landscapes of Arctic / B. N. Gorodkov // Botanical journal. - 1954. - Vol. 39, № 1. - pp. 16-29.

125. Kalyakin, V. N. Mammals in ecosystems of the south of Yamal / V. N. Kalyakin // Mammals in ground ecosystems. - M. : Science, 1985. - pp. 67-99.

126. Kalyakin, V. N. On dissemination of some mammals, amphibians and reptiles in the far North-East of Europe and in the south of Yamal / V. N. Kalyakin // Bulletin of MSN. Biological department - 2002. - Vol. 107, issue 2. pp. 23-30.

127. Kuzmina, I. E. Hourses of Northern Eurasia from the Pliocene to modern times // Proceedings of Zoological Institute of RAS. - 1997. - Vol. 273. - 223 p.

128. Alkseeva, L. I. Subfossil horses of Moscow district / I. E. Kuzmina // Bulletin of CRQ. - 2001. - № 64. - pp. 32-34.

129. Geptner, V. G. Mammals of the Soviet Union / V. G. Geptner, A. A. Nasimovich, A. G. Bannikov. - M. : Higher school, 1961. - Vol. 1. Artiodactyles and perissodactyles. $-776 \mathrm{p}$.

130. Boeskorov, G. G. The red deer in the Pleistocene in North-Eastern Asia and Alaska / G. G. Boeskorov // Theriofaune of Russia and adjacent territories : proceedings of the International meeting, 6 February 2003 - M., 2003. pp. 55-56.

131. Smirnova, O. V. The role of key species in preserving forest biodiversity / O. V. Smirnova // Russian Conservation News. - 1998. - № 15. - Spring. - P. 17-18.

132. Forest map of the Russian Federation, colored by prevailing groups of tree species and canopy density (scale 1: $14000000)$ / S. A. Bartalev, D. V. Ershov, A. S. Isaev, P. V. Potapov, S. A. Turubanova, A. Y. Yaroshenko. - M., 2004. $-1 \mathrm{p}$.

133. Rysin, L. P. Spruce forests of Russia / L. P. Rysin, L. I. Savelyeva. - M. : Science, 2002. - 335 p.

134. The red book of the Russian Federation. Animals. - M. : Ast, 2001. - 392 p.

135. Popov, M. G. On the issue of the taiga origin / M. G. Popov // Collected papers on results of examination in the field of forestry and forest industry in the taiga zone of USSR. - M. ; L. : Publishing of AS USSR, 1957. - pp. 19-28.

136. Baranov, V. I. Stages of flora and vegetation development in USSR in the Tertiary period / V. I. Baranov. - Kazan : Publishing of KSU, 1954. - 362 p.

137. Vasylyev, V. N. Origin of flora and vegetation of the Far East and Eastern Siberia / V. N. Vasylyev // Materials on the history of flora and vegetation of USSR. - M. ; L. : Publishing of AS USSR, 1958. - Issue 3. - pp. 361-457.

138. Udra, I. F. Interpretation of the paleogeographic situation of Polesye and adjacent regions on the basis of botanical data / I. F. Udra // Botanical journal. - 1982. - Vol. 67, № 1. - pp. 94-100.

139. Evstigneev, O. I. Population strategies of tree species / O. I. Evstigneev // Eastern European forests: the history in the Holocene and modern times. - M. : Science, 2004. - Book 1. - pp. 176-204.

140. Pachosky, I. K. Main features of flora development in South-Western Russia / I. K. Pachosky // Proceedings of Novorossiysk society of naturalists. - Kherson, 1910. - Issue $34 .-430 \mathrm{p}$.

141. Lavrenko, E. M. History of flora and vegetation of USSR by data on modern dissemination of plants / E. M. Lavrenko // Vegetation of USSR. - M. ; L. : Publishing of AS USSR, 1938. - Vol. 1. - pp. 235-296.

142. Shtegman, B. K. On the origin of taiga avifauna / B. K. Shtegman // DAS USSR. - 1931. - Series A. - № 13. pp. 350-357.

143. Micromosaic organization and phytomass of soil cover in main types of dark coniferous forests of the PechoraIlych reserve / D. L. Lugovaya, O. V. Smirnova, M. V. Zaprudina, A. A. Aleynikov, V. E. Smirnov // Ecology. 2011. - № 1. - pp. 3-10. 